\title{
Green-bricks: An empirical approach of shocks in soybean prices to residential building in Rosario, Argentina. ${ }^{1}$
}

Federico Mario Accursi ${ }^{2}$

\section{Resumen}

Los shocks en los precios internacionales de los commodities afectan a los países en vías de desarrollo tanto en sus agregados macroeconómicos, como a nivel sectorial. El objetivo de este trabajo es estudiar el impacto del precio internacional de la soja en la actividad de la construcción en la ciudad de Rosario, epicentro agrícola de la Argentina, uno de sus principales productores. Se utiliza la metodología de vectores autorregresivos (VAR) la cual registra un efecto positivo para el período 1994-2018. El efecto se visualiza en el primer año y medio, donde la elasticidad de un impulso transitorio en el precio de la soja puede variar entre 0.69 y 0.96 .

Palabras claves: shock de precios, commodities, VAR, función de impulso-respuesta, construcción inmobiliaria

\section{Abstract}

Shocks in commodity prices affect developing countries not only on their macroeconomic aggregates, but also on specific industries. The aim of this paper is to study the impact of international soybean prices on the construction activity in Rosario, epicenter of the most fertile area in Argentina, a major soybean producer. VAR methodology is used and accounts for a positive effect in the period 1994-2018. The time path of the effect would be along the first year and a half, when the elasticity of a transitory impulse in soybean prices ranges between 0.69 a 0.96 .

Keywords: price shocks; commodities, VAR, impulse response function, real estate

JEL: C32, Q02, O10, R00

DOI: https://doi.org/10.46553/ensayos.3.2.2020.p101-128

Fecha de recepción: 02/08/2019; Fecha de aceptación: 09/06/2020

\footnotetext{
${ }^{1}$ This paper is my thesis work done to obtain the Master in Economics degree at Universidad de San Andrés. I would like to thank to Javier García Cicco for all his support and patience.

${ }^{2}$ Universidad Austral. E-mail: faccursi@austral.edu.ar
} 


\section{Introduction}

The motivation of this paper is essentially to study the impact of commodity prices, specifically soybean, into the real estate activity in the port city of Rosario, Argentina. I adopt the VAR methodology and the impulse response function in order to measure that effect.

The common of the literature has focused on macroeconomic aggregates. The commodity rising prices in the last decade and its volatility have been studied from different sides: Dutch disease, impact on private investment or exporting behavior. For example, Koitsiwe y Adachi (2015) studied the Australia mining boom using the VAR methodology and Pedersen (2015) did something similar with the impact of different types of copper market shocks into the Chilean economy. Finally, Muñoz (2013) uses a panel data and finds a negative relationship between the impacts of commodity prices on debt spread in emerging countries, which is larger as the exports are more concentrated.

As far as I know, few investigations try to glimpse the effect on a specific sector at a local level. For instance, Grimes and Hyland (2013) use the VAR methodology and study the effect of commodity prices variations on urban and rural outcomes, such as national housing and farm prices in New Zealand. They find that a raise in commodity prices leads to a permanent increase in housing investment and house prices. In addition, Shi and Tang (2013) investigate the relationship between commodity and house prices in Australia and New Zealand; Sing et al (2015) try to forecast private sector construction using Hong Kong private residential market data.

In Latin America, and particularly in Argentina, highlights the extensive work of Cornejo (2017) in her thesis, as well as Curcio et al (2014). According to Cornejo, using data between 1980 and 2013, the Argentinean GDP depends positively in the long term on commodity prices: $1 \%$ finally affects $0.23 \%$ the GDP; and agricultural prices Granger cause it. In addition, she finds one common cycle shared between them along the 2000-2013 period.

To sum up and to the best of my knowledge, the main contribution of this paper to the literature would be the study of the impact of commodity prices into a specific sector and city: building activity in Rosario, a town which largely depends on them.

The paper follows with Section 2 that provides an economic framework and contextualize this empirical work; Section 3 shows descriptive statistics and tests performed to check stationarity. Section 4 describes briefly the methodology; Section 5 and 6 states the main results and robustness checks, and finally Section 7 concludes. 


\section{Economic framework}

The building activity, in particular residential, produces a particular asset which not only provides housing services but also entails a particular way of saving money and makes it a financial asset. In fact, Bebzuck and Garegnani (2012) using an Equilibrium Correction model found empirical evidence for the case of Argentina, that Real State is housing and financial investment as well.

From this economic point of view, the demand of new residential buildings will come naturally from the population growth, and as an alternative financial asset which competes with others in terms of returns, risk, and liquidity.

The hypothesis stated in this paper is that the building activity is fostered not only by the local activity (because construction is procyclical), but also by the surplus of the agrarian activity that would have financed the activity. The way that shock prices would affect residential building is portrayed in Figure 1.

Figure 1: The plausible effects of soybean prices

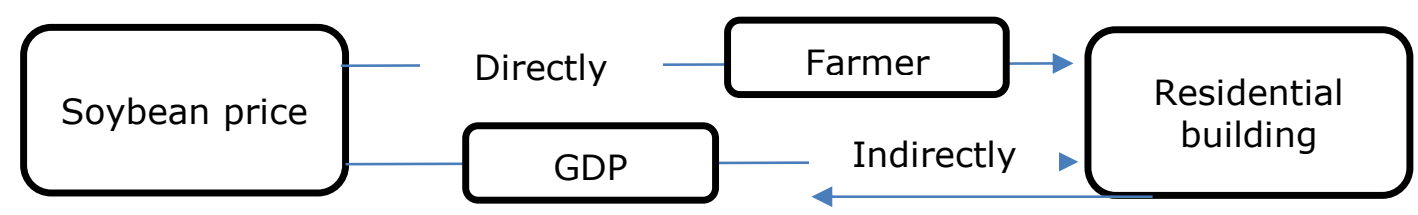

According to Friedman permanent income hypothesis, positive and transitory shock in income turns into an increase in savings, while a permanent shock affects consumption. On the one hand this means that, if producers perceive changes in soybean prices as transitory, this will be coherent with an increase in residential building activity directly. On the other hand, if those changes are perceived as permanent, consumption (and GDP) will grow, and the effect on residential building would be indirect and most probably lower.

Moreover, from a general microeconomic perspective, no matter the nature of price change (whether transitory or permanent) the effect will probably fade out as profits tend to zero. In a perfect competitive framework, the more profitable the agrarian sector is, the more economic agents will try to capture that surplus by increasing input costs (seeds, agrochemicals, or land rent) or increasing taxes (e.g. export taxes in the Argentinean case).

The soybean election as the commodity price is straightforward. The importance of this crop for the region is indubitable: $80 \%$ of the Argentinean soybean oil and more than $60 \%$ of the crop is produced in the core area -the most fertile land in Argentina, locally known as "zona núcleo"- where Rosario is the commercial and logistic epicenter.

Parallel to the "boom" in the soybean price in the middle 2000s, it is the important 
expansion in construction in Rosario. According to the Municipality of Rosario, the urban area grew $5.2 \%$ in 2003-2010. ${ }^{3}$ Lapelle et al. (2011) argued that the postdevaluation scenario and the distrust in the financial sector post financial crisis in 2001-2002, were the main reasons of the take off the construction sector. Many trusts were created and orientated to the construction of new buildings in Rosario, and the activity flourished up to 2008 , when a new urban code was pronounced in March and the conflict between the National Government and the rural sector became tougher because of the creation of mobile system for export taxes. ${ }^{4}$ Moreover, the international financial crisis shocked the commodities markets turning them more volatile. The soybean price fell $30 \%$ in the last quarter of 2008 in comparison with the third one, and export taxes for soybean were at $35 \%$.

The common view in Rosario was that money had moved from the rural area to the construction activity. The theoretical reason as mentioned above is clear: the surplus generated by devaluation and better prices- was redirected to Real State in a context where the memory of banking crisis in 2002 was still fresh.

The aim of this paper is neither modelling the building investment nor forecasting. I adopt VAR methodology and the impulse response function in order to estimate the effect of exogenous movements in soybean prices of Gulf of Mexico -as a proxy of profits $^{5}$ - on two different measures of construction activity.

\section{Data}

The main data used is quarterly from 1994 to 2018 and includes: FOB Gulf soybean price in dollars, the authorized area for construction in Rosario in thousands of square meters (m2) and its subset -new residential buildings- also measured in thousands $\mathrm{m} 2$, real GDP, real interest rate and an index of building costs in dollars. Table 1 shows the main descriptive statistics, and data appendix contains details of each series. All variables are later transformed in logarithms, except real interest rate. Identifiable seasonality is tested using $\mathrm{X}-13$ ARIMA-SEATS program.

\footnotetext{
${ }^{3}$ We are not taking into account the Metropolitan Area (Funes, Roldán, Pérez, Granadero Baigorria) which its growth rate has been higher. Unfortunately, that data is not available.

4 The Resolution 125/2008 from the Ministry of Economy declared a mobile export tax that according to soybean prices in March rose to $43 \%$. The conflict lasted from March to July.

${ }^{5}$ Although Bus and Nicolini (2010) calculated that in Argentina the elasticity for rent for the soybean depends firstly on yield, then on international FOB price and lastly on costs, it is difficult to convert annual yields into quarterly data without some arbitraries assumptions
} 
Table 1: Descriptive statistics of original series

\begin{tabular}{|c|c|c|c|c|c|c|}
\hline Variable & Sample & $\mathbf{N}$ & Mean & Std. Dev. & Min & Max \\
\hline Gulf soybean price (US\$) & $\begin{array}{l}1994 q 1- \\
2018 q 4\end{array}$ & 100 & 333.9 & 122.2 & 174 & 653 \\
\hline Building permits (in thousands $\mathrm{m}^{2}$ ) & $\begin{array}{l}1994 q 1- \\
2018 q 4\end{array}$ & 100 & 158.2 & 62.6 & 40.6 & 374.9 \\
\hline $\begin{array}{l}\text { New Residential permits (in thousands } \\
\mathrm{m}^{2} \text { ) }\end{array}$ & $\begin{array}{l}1994 q 1- \\
2018 q 4\end{array}$ & 100 & 82.8 & 40.9 & 19.6 & 200.1 \\
\hline Real GDP (constant 2004 millions \$) & $\begin{array}{l}1994 q 1- \\
2018 q 4\end{array}$ & 100 & 575,879 & 115,596 & 406,169 & 748,521 \\
\hline Real Interest rate $(\%)$ & $\begin{array}{l}1999 q 1- \\
2018 q 4\end{array}$ & 80 & -2.9 & 11.4 & -31.9 & 32.7 \\
\hline Building cost Index in dollars & $\begin{array}{l}1994 q 1- \\
2018 q 4\end{array}$ & 100 & 96.4 & 25.1 & 36 & 137.9 \\
\hline
\end{tabular}

Note: Seasonality was found in Building permits only. The seasonally adjusted series will be used hereinafter.

Taking a glimpse at Figure 2, we can see a strong correlation between both series of construction, which in fact is 0.90 . Building permits has an outlier in 2000q3, when an important commercial mall was authorized, and seasonality could be induced observing the recurrent peaks at the last quarter of each year. Building permits include any type of structure, whether for health, education or for commerce.

In figure 3 soybean prices and new residential permits are compared. They seem to share the same pattern from 1998 to 2008, discontinues up to 2010, and then they share volatility in a kind of steady state or mild downward trend. Linear correlation is 0.66 , slightly higher than the 0.58 between building permits and soybean price.

Figure 2: Building and new residential permits

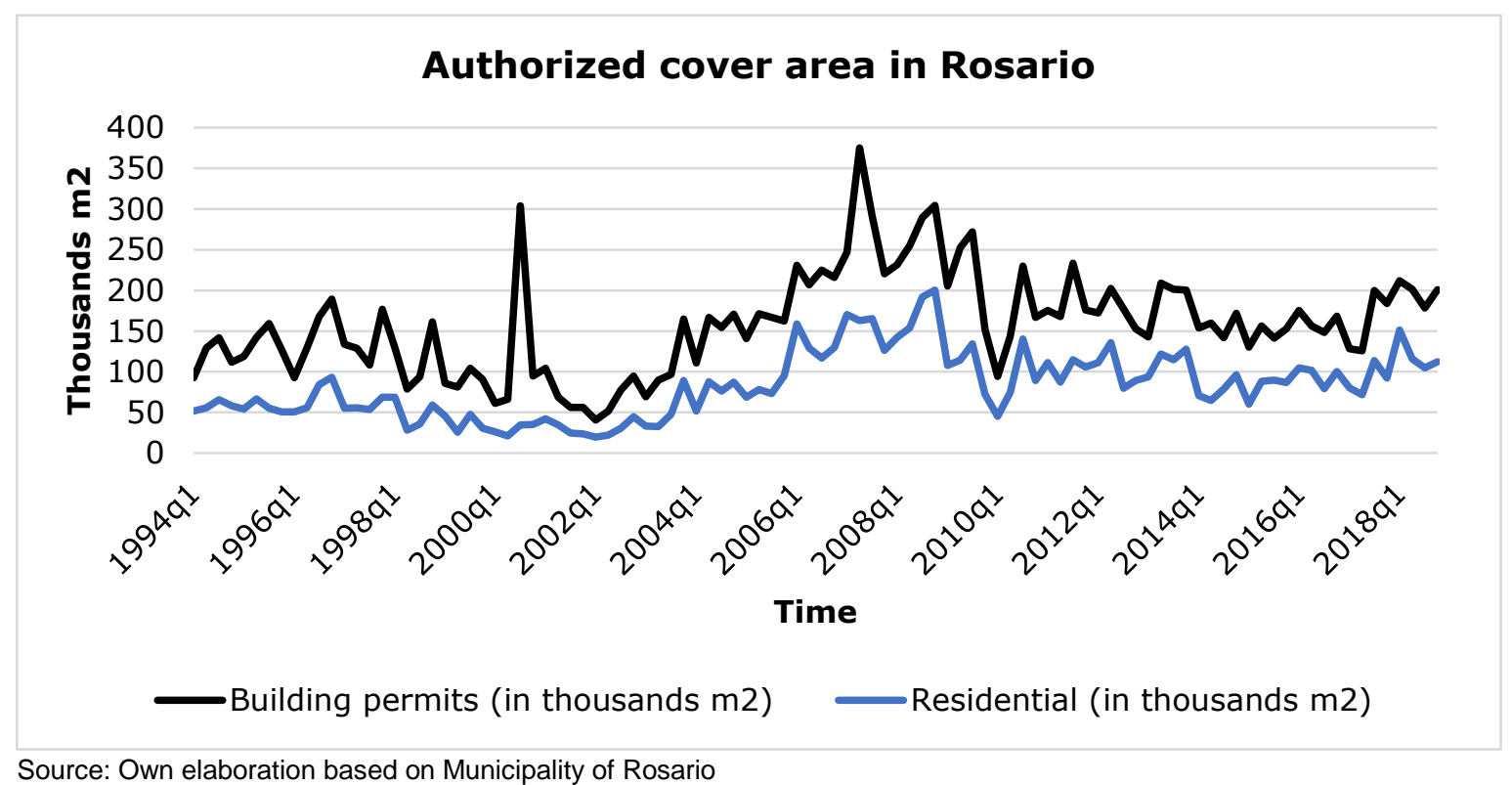

Source: Own elaboration based on Municipality of Rosario 


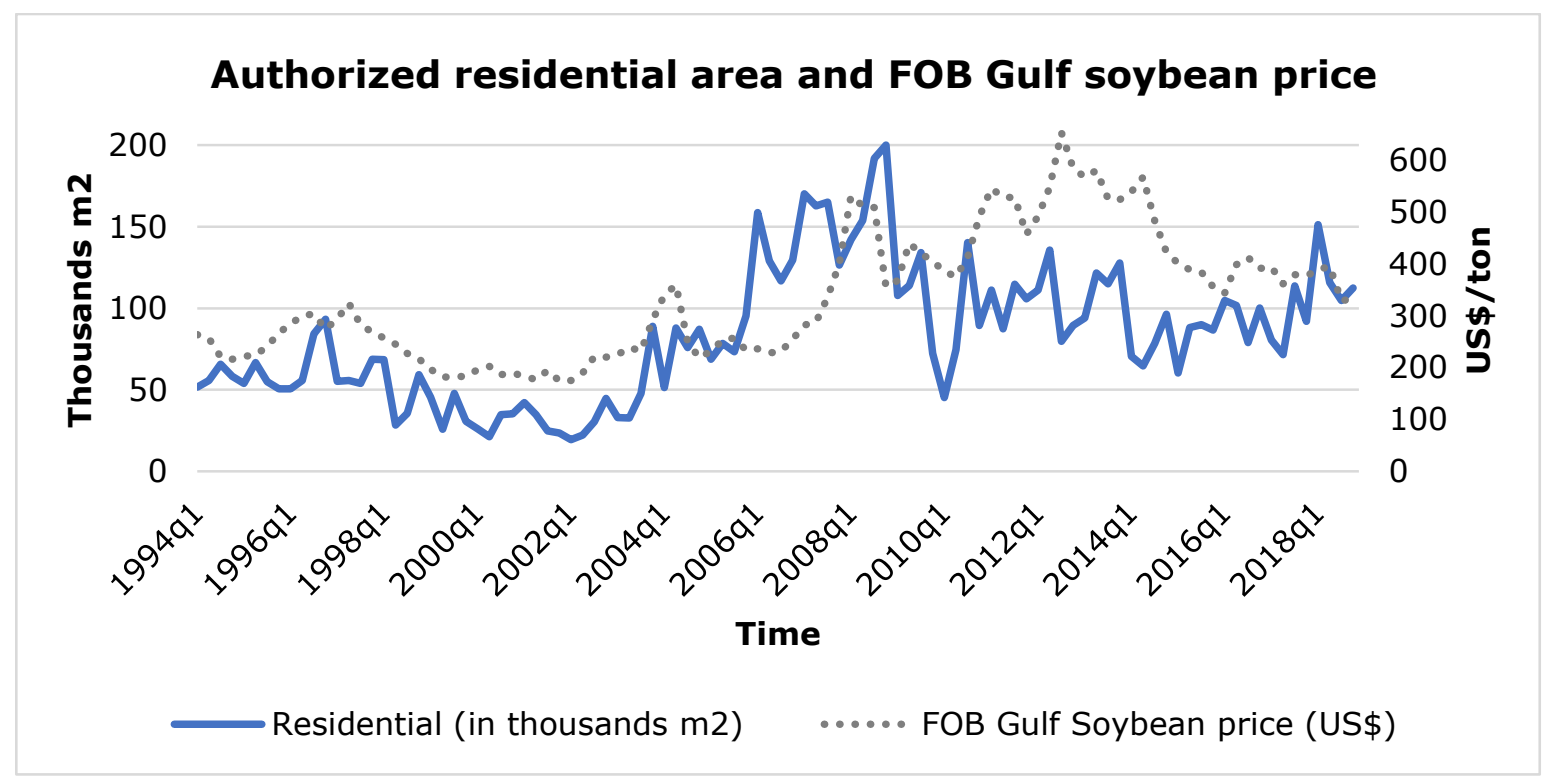

Source: Own elaboration based on Municipalidad de Rosario and Argentina Ministry of Economics

In Table 2 different unit root tests are resumed. The classical Augmented DickeyFuller, and a modified version using generalized least-square regression by Elliot, Rothenberg and Stock (1996) are the first tests estimated. The latter test has more power than the traditional ADF. The third unit root test performed is Phillips and Perron (1988) that uses Newey-West standard errors, which are robust to serial autocorrelation. Finally, when a structural break would be present, Enders (2004) warns: "(...) the Dickey Fuller test is biased toward accepting the null hypothesis of a unit root even though the series is stationary within each of the sub periods" (p. 201). Consequently, a modified version of the ADF test robust to the presence of one structural change is performed: Zivot and Andrews (1992).

Soybean prices and GDP would follow a random walk as any test could not reject the null hypothesis of the presence of unit root. Regarding building costs, only DF-GLS would indicate a stationary process in levels. However, looking at its graph in the appendix, it seems to have at least one structural break. It would be stationary up to the strong devaluation of 2002, but then starts a clear upward trend followed by a sort of volatile stationary state which depends on devaluation episodes of the currency. According to the Zivot and Andrews (ZA) test, the null hypothesis of a unit root even in the presence of one structural break cannot be rejected. Therefore, I assume that building cost, soybean price and GDP series follow a random walk process and they are $\mathrm{I}(1)$, as it can be determined by the unit root tests performed to differenced series.

According to Phillips-Perron and ZA unit root tests, real interest rate would be either mean or trend stationary. This series might have one structural break in levels and at least an outlier in 2002q1. In order to detect unknown dates of structural breaks, I follow Bai and Perron (1998) and Bai (1997). The proceeding is firstly testing the presence of a structural change in the whole sample, and only if a structural break is found, follow testing in the two sub-samples. The first structural break found is in 
2001q4, and there are some breaks found before that date in the first sub-sample, but not afterwards.

Finally, the two series of construction present mix results and it is difficult to come to a doubtless conclusion. As Enders (2004) states: "A trend stationary process can arbitrarily well approximate a unit root process. If the stochastic portion of the trend stationary process has sufficient variance, it will not be possible to distinguish between the unit root and trend stationary hypothesis" (p.209). In addition, "many macroeconomic variables are not characterized by unit root processes and they are trend stationary processes joined with structural breaks, instead". (Enders, 2004, pp. 205).

Consequently, in order to allow the possibility of having stationary series with a structural break, two more series are estimated: real interest rate and building permits filtered. These series are the residuals of a third-grade polynomial trend with one structural break detected by Bai and Perron methodology. ${ }^{6}$

Table 2: Summary of unit root tests

\begin{tabular}{|c|c|c|c|c|c|c|c|c|c|}
\hline & \multicolumn{3}{|c|}{ ADF Unit root tests } & \multicolumn{2}{|c|}{ DF-GLS } & \multicolumn{2}{|c|}{ Perron } & \multicolumn{2}{|c|}{ Zivot and Andrews } \\
\hline Variable & lag & Level & $\begin{array}{c}\text { Level } \\
\text { and trend }\end{array}$ & Level & $\begin{array}{l}\text { Level } \\
\text { and } \\
\text { Trend }\end{array}$ & Level & $\begin{array}{c}\text { Level and } \\
\text { Trend }\end{array}$ & $\begin{array}{l}\text { Allowing } \\
\text { break in } \\
\text { constant }\end{array}$ & $\begin{array}{c}\text { Allowing } \\
\text { break in } \\
\text { level or } \\
\text { trend }\end{array}$ \\
\hline ln soybean price & 8 & -1.2 & -1.9 & -1 & -1.6 & -1.5 & -2.1 & -3.9 & $\begin{array}{l}-4.0 \\
\end{array}$ \\
\hline$\Delta \ln$ soybean price & 7 & $-3.9 * * *$ & $-3.9 * *$ & $-3.3^{* * * *}$ & $-3.7 * * *$ & $-7.8^{* * * *}$ & $-7.8 * * *$ & $-7.3 * * *$ & $-7.3^{* * * *}$ \\
\hline In Building (SA) & 11 & -1.8 & -2.5 & -1.5 & -2.4 & $-3.3 * *$ & $-3.8 * *$ & -4.5 & $-4.9 *$ \\
\hline$\Delta \ln$ Building (SA) & 10 & $-2.6^{*}$ & -2.6 & -0.8 & -1.6 & $-15.6^{* * * *}$ & $-15.5^{* * * *}$ & $-14.9 * * *$ & $-14.9 * * *$ \\
\hline In Residential & 2 & -1.6 & -2.2 & -1.3 & -2.0 & -2.4 & $-3.2 *$ & -3.7 & -3.9 \\
\hline$\Delta \ln$ Residential & 1 or 2 & $10.4^{* * *}$ & $-8.5 * * *$ & $-9.3 * * *$ & $-7.9 * * *$ & $-14.0 * * *$ & $-13.9 * * *$ & $-9.2 * * *$ & $-9.2 * * *$ \\
\hline $\ln$ GDP & 1 or 2 & -1.0 & -2.8 & 0.2 & -2.0 & -1.0 & -1.7 & -3.4 & -3.2 \\
\hline$\Delta \ln$ GDP & 1 & $-4.9 * * *$ & $-7.2 * * *$ & $-4.3^{* * *}$ & $-7.1^{* * *}$ & $-7.3^{* * * *}$ & $-7.3 * * *$ & $-8.3^{* * *}$ & $-8.5^{* * *}$ \\
\hline Real interest rate & 7 or 5 & -1.8 & -2.0 & -0.8 & -2.7 & $-4.5^{* * * *}$ & $-5.7 * * *$ & $-5.8 * * *$ & $-5.8 * * *$ \\
\hline$\Delta$ Real interest rate & 4 or 11 & $-7.1 * * *$ & -2.9 & $-7.3^{* * *}$ & -0.4 & $-11.9 * * *$ & $-11.8 * * *$ & $-8.4 * * *$ & $-8.4^{* * * *}$ \\
\hline In Building costs & 1 & -2.1 & -2.2 & $-1.9 *$ & -1.9 & -1.8 & -1.9 & -3.6 & -4.1 \\
\hline$\Delta \ln$ Building costs & 0 & $-7.1^{* * *}$ & $-7.0 * * *$ & $-7.1 * * *$ & $-7.1 * * *$ & $-7.0 * *$ & $-7.0^{* * * *}$ & $-8.1^{* * *}$ & $-8.4^{* * * *}$ \\
\hline In BuildingSA_filtered & 11 & $-4.2 * * *$ & $-4.2 * * *$ & $-4.1 * * *$ & $-4.1 * * *$ & $-7.7 * * *$ & $-7.7 * * *$ & & \\
\hline real interest_filtered & 1 & $-8.1 * * *$ & $-8.1 * * *$ & $-7.2 * * *$ & $-7.9 * * *$ & $-7.2^{* * *}$ & $-7.2 * * *$ & & \\
\hline
\end{tabular}

Note: ${ }^{* * *}$ means that the null hypothesis has been rejected at $1 \%$ significance level; ${ }^{* *}$ at $5 \%$, and ${ }^{*}$ at $10 \%$. The optimal lag used for ADF and DF-GLS is calculated following de Ng-Perron sequence. When two lags are stated is because one lag option is for level, and the other for the option "level and trend". SA means "Seasonally adjusted". The filtered series are the residuals of a third-grade polynomial trend with one structural break: 2003q3 in building permits and 2001q4 in real interest rate.

\footnotetext{
${ }^{6}$ Although more than one structural break is found, I just model one structural break with the date found by methodology. The reason is strictly for simplicity.
} 


\section{Methodology}

In order to see the effect of soybean prices shocks on construction activity in Rosario, I estimate the orthogonal impulse response function (OIRF) from a vector autoregression model. Depending on the order of integration and the relationship between series the OIRF is estimated from a Vector Error Correction Model -when series are I(1) and are cointegrated-; from a VAR in differences if series are I(1) but not cointegrated; and finally from a VAR in levels if series are I(0).

As Enders (2004) explains, an error-correction specification can be expressed as:

$\Delta x_{t}=\pi_{0}+\pi x_{t-1}+\pi_{1} \Delta x_{t-1}+\pi_{2} \Delta x_{t-2}+\ldots+\pi_{p} \Delta x_{t-p}+\varepsilon_{t}$

where $x_{\boldsymbol{t}}$ is $(\mathrm{n} \times 1)$ vector of $\left(x_{1 t,}, x_{2 t}, \ldots, x_{n t}\right) \mathrm{T}, \pi_{0}$ is $(\mathrm{n} \times 1)$ vector of intercepts terms; $\pi_{i}$ is $(\mathrm{n} \times \mathrm{n})$ coefficient matrices, $\pi$ is a matrix which at least one of its element out of the diagonal is different from zero, and $\varepsilon_{t}$ is $(n \times 1)$ vector with elements $\varepsilon_{j t}$, where $\varepsilon_{j t}$ may be correlated with $\varepsilon_{i t}$. If all variables are $\mathrm{I}(1)$ and there is an error correction representation as in (1), there is necessarily a linear combination of the $I(1)$ variables which is stationary. From equation (1) we can obtain:

$$
\pi x_{t-1}=\Delta x_{t}-\pi_{0}-\Sigma \pi_{i} \Delta x_{t-i}-\varepsilon_{t}
$$

In specifying VECMs, the lag order, the cointegration rank and possibly further restrictions have to be determined. The lag order and the cointegration rank are typically determined before further restrictions are imposed on the parameter matrices. Moreover, the specification of a VECM usually starts by determining a suitable lag length because, in choosing the lag order, the cointegration rank does not have to be known, whereas many procedures for specifying the cointegration rank require knowledge of the lag order (Lüktepohl, 2005: 325).

Matrix $\pi$ in equation (2) is essential. If all its elements are zero, equation (1) is a traditional VAR in first differences. Otherwise, if one or more of its elements out of the diagonal are different from zero, a VAR in differences would be inappropriate. Finally, if it is full rank it means all variables are $\mathrm{I}(0)$. Johansen cointegrated tests are based on two statistics: the trace and the maximum eigenvalue statistics in order to determine the rank order of the matrix. Performing this test requires the lag order. Lüktepohl (2005) says the criteria $\mathrm{HQ}$ and SC are consistent, and that consistency is maintained for integrated processes. Therefore, based on that information criteria, Johansen cointegration tests are performed and they are available in Appendix C.

For example, if there are two variables $(\mathrm{K}=2)$, we first test $\mathrm{rk}(\pi)=0$. If this null hypothesis cannot be rejected, the analysis proceeds with a cointegration rank of $r=0$ and, hence, a model in first diff erences is considered in the subsequent analysis. If, however, $\operatorname{rk}(\pi)=0$ is rejected, we test $\operatorname{rk}(\pi)=1$. If this hypothesis is not rejected, the analysis may proceed with a VECM with cointegrating rank $r=1$. Otherwise $\operatorname{rk}(\pi)=2$ is tested and if rejected, one may consider working with a stationary VAR model for the levels of the variables (Lüktepohl, 2005). 
Following Hamilton (1994) a reduced and restricted VAR form is

$y_{t}=\beta Y_{t-1}+\epsilon_{t}$

where $\boldsymbol{y}_{\boldsymbol{t}}$ is the $(k \times 1)$ vector of endogenous variables, $\boldsymbol{\beta}$ is $(k \times(p+1))$ matrix of coefficients where $p$ is the maximum lag, and $\boldsymbol{Y}_{\boldsymbol{t}-\mathbf{1}}$ is a $(k \times(p+1))$ matrix containing the lagged values of the variables in $y$ as well as the constant term, and $\epsilon t$ is a serially uncorrelated error term where $\mathrm{E}\left(\epsilon_{t} \varepsilon_{t-1}^{\mathrm{T}}\right)=\boldsymbol{\Omega}$ ) para $t=\tau$, and zero otherwise. $\boldsymbol{\Omega}$ is the contemporaneous covariance matrix.

The structural VAR takes the form

$A y_{t}=B Y_{t-1}+\mu_{t}$

Where $\boldsymbol{A}$ is a matrix of contemporaneous relationship, $\boldsymbol{\beta}=\boldsymbol{A}^{\mathbf{- 1}} \boldsymbol{B}, \boldsymbol{\mu}_{\boldsymbol{t}}$ are the structural shocks, and $\mathrm{E}\left(\boldsymbol{\mu}_{t} \boldsymbol{\mu}_{t-1}^{\mathrm{T}}\right)=\boldsymbol{D}$ for $t=\tau$, and zero otherwise, where $\boldsymbol{D}$ is a diagonal matrix. Identification of shocks to international soybean prices is achieved by assuming a lower triangular form for $\boldsymbol{A}$ (when the soybean price is ordered first in the vector $y$ ), and by imposing also a block-exogenous structure in $\boldsymbol{B}$ by which the price of soybeans can only be affected by its own lagged values, but not by lagged values of the other variables. The key assumption and, therefore the key parameter restriction in any version of the VAR system I will estimate is the weakly exogenous nature of Gulf soybean prices.

As it was stated in the previous section, the presence of a unit root is unclear for residential, building and real interest rate series. Consequently, I follow a pragmatic and skeptic approach. Firstly, it is assumed that they are I(1) and a Johansen test is performed in order to be modelled as a VECM or as a VAR in differences. Then, if residential permits series is assumed to be I(0), a VAR in "levels" is estimated using the soybean price differenced (because it is integrated of order 1 ) and the original series of residential permits.

I begin the analysis using a bivariate model with the variables of interest: residential permits and Gulf soybean price. Then, we extend the analysis including all variables in a full model specification. Afterwards, the estimation is performed using the building permits instead of residential, and the real interest rate is introduced as a new covariate. Its inclusion tries to capture other financial investment opportunities.

In all cases I follow the Schwartz-Bayesian (SBIC) information criterion for the number of lags in the Johansen test. Afterwards, the number of lags in either VECM or VAR model, is chosen according to interfomation criteria and model diagnostic. All models are estimated using STATA except VEC models, which are estimated using JMulti. The OIRF confidence intervals from VEC models are estimated using Hall procedure, since it has more desirable characteristics than the alternative Efron, which has an implicit asymptotic unbiasedness assumption (Lüktepohl, 2005). Regarding OIRF confidence intervals calculated from VAR models, are estimated using bootstrapped standard errors with 500 replications 


\section{Empirical results.}

Let's begin assuming that residential permits are a random walk. Following the Bayesian information criterion of one lag, the Johansen trace statistic gives evidence of one cointegration rank. Specifying a VEC model and restricting some coefficients because of the assumption of soybean price weak exogeneity, the effect is statistically significative but vanishes before the year. A permanent change in soybean price $(10.6 \%)$ entails a positive change in residential building permits $(8.8 \%)$ in the third quarter, and then converges to a positive permanent change (12\%) without being statistically signifcative anymore.

Would it be possible to have a permanent shock in prices with a lasting effect over residential investments in Rosario? Theoretically, it would be very difficult. Higher prices lead to more construction only if profits remain high and building is still an adequate investment opportunity.

Regarding profits, the extraordinary rent would be tough to maintain for the producer even when prices remain at a higher level- because agricultural commodity markets show a competitive structure (Evenett and Jenny, 2012). Sooner or later, "rent seeking behavior" of suppliers turns up: more demand of seeds, fertilizers, pesticides will probably increase their prices; land value rises and farmland rental grows in paralell; or even the Government may be tempted to establish new taxes or raise the existing ones. The only way for profits to remain in Rosario region, is by knowing who owns land. Because of its low supply elasticity, local landowners would benefit from a higher permanent price. Even though local landowners were permanently richer, consumption would increase instead of savings according to Friedman income hypothesis (Friedman, 1957).

Concerning as an opportunity of investment, as long as construction would be a profitable investment, it would still attract capital. This could be the case of the Real Estate market in Rosario as Lapelle et al. (2011) explains, since it has experienced a higher investment yield than stock Exchange or bank deposits, at least for the period 2003-2010.

So far, the idea of a permanent change in prices leading to permanent changes in residential permits, though possible, can be improved by another hypothesis with more theoretical foundation -remember the Friedman income hypothesis in Section 2-. If changes in prices had been perceived as transitory, people would have invested that extraordinary rent.

This second hypothesis is represented in the VAR model with residential permits in levels. In this case, I am assuming that housing permits is stationary. A $9.8 \%$ shock in prices rapidly goes down and entails an effect on residential permits reaching a maximum of $7.9 \%$ after a year, and then it fades out. This time path would be

\footnotetext{
7 The lease of fields for soy grew 25\% in the campaign 2005/2006 in comparison with the average of the previous four years, according to "Compañia Argentina de Tierras".
} 
reasonable twofold: it is theoretically backed, and it follows the soybean cycle quite well. If we imagine a simplified situation where the farmer seeds and waits six months up to the harvest, then it will have another six months to think where to invest the money. This is coherent with Lapelle et al. (2011) description for Rosario.

Regardless the price change nature, the real perceptions of economic agents -which are unknown- are the clue. By the second term (the harvest period in Argentina) of 2004 prices were $50 \%$ higher than second term of 2003 and $78 \%$ higher than average prices of the previous five years. Despite prices fell down in 2005, the rent gained in the previous campaign was spilled over the construction sector. Moreover, a recovering economy, lower building costs in dollars and a collapsed financial system also encouraged the sector. According to the permanent income theory, if that shock of income was perceived as transitory, savings would have increased, particularly in the form of investment in bricks.

All in all, both models, independently whether price changes are permanent or transitory, give statistical evidence of a transitory effect in the short term. Reasonably, as the shock remains in the permanent specification, the effect is larger than in VAR. From the modelling point of view, the difference between permanent and transitory is clear; what is not is in the perception that economic agents have about the change price nature when it occurs.

To conclude this section, the Granger causality test is performed in the unrestricted VAR. It gives evidence that housing permits Granger cause soybean prices ${ }^{8}$ and not vice versa. Although housing permits helps predicting soybean prices in the unrestricted VAR system, the exogeneity assumption of prices is still being reasonable since it is difficult to think there is a link between Rosario's Real Estate and the world market of soy, in which the former can affect the latter.

\footnotetext{
${ }^{8}$ In the bivariate model, Granger causality tests gives statistical evidence only in the direction of soybean prices being Granger caused by residential permits. In the full model, soybean prices either Granger causes residential or building permits. Estimations are available upon request.
} 
Figure 3: OIRF for bivariate model
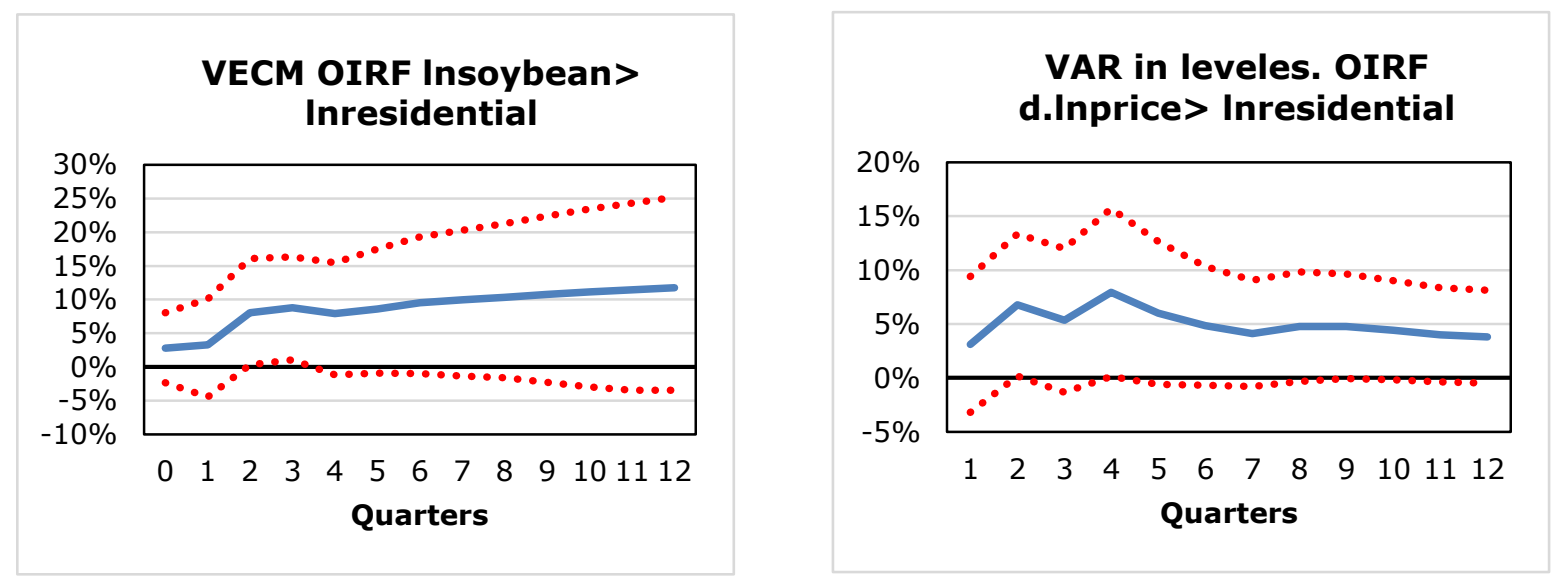

Notes: a- The restricted VEC models contain one constraint that reflects the weak exogeneity of soybean prices $($ alpha $=0)$ in the error correction term. Its VAR representation is a VAR(3). Estimation procedure: two stage. First: Johansen approach. Second: EGLS. $95 \%$ Hall percentile bootstrap confidence intervals based on 500 bootstrap replications. b- VAR(4) $95 \% \mathrm{Cl}$ bootstrapped standard errors

\section{Robustness checks.}

In this section I extend the analysis introducing more covariates. Three variants are taken into account. Firstly, GDP and building costs in dollars are introduced into the system creating the full model specification. The purpose is to measure the feedback between variables portrayed in Figure 1 . Secondly, real interest rate is introduced into the bivariate system with the aim of adding a sort of opportunity cost of investment. It is expected a negative effect: the lower the interest rate, the cheaper is to borrow money in real terms, and investment in capital goods is therefore encouraged. Finally, I replace the variable of interest (residential permits) by a broader one: building permits. Although strictly speaking it is not a robustness check, it is informative to see how a similar variable behaves.

In the full model specification -where GDP and costs get into the system- the conclusion of the Johansen cointegration test is not straightforward since the trace and the maximum eigenvalue conclusions disagrees. According to Lüktepohl et al. (2001), the local power of both tests is very similar but there can be differences in small samples, where the trace test tend to have more power in some situations. With this caveat, I estimate a VECM with one cointegration equation.

Results are portrayed in Figure 4. In the VEC model the effect would be a bit larger than the bivariate model and statistically significant through time. After a year, the effect reaches $10.8 \%$ and converges to almost $14 \%$. In the VAR in levels, however, its maximum is reached in the fifth quarter $(9.4 \%)$ and then goes down. 
Contrasting bivariate and full models, on the one hand one should expect a larger effect, since the effect of prices on GDP will theoretically go in the same direction and will reinforce the positive effect. On the other hand, higher prices could also induce an appreciation effect which will prompt higher costs in dollars, and finally reduce investment in construction.

In the VEC specification, the full model has a barely larger effect in short term, but the main difference is that the effect lasts in time. While in the bivariate model was not reasonable, now it is, due to the feedback between variables.

Figure 3: OIRF for Full model
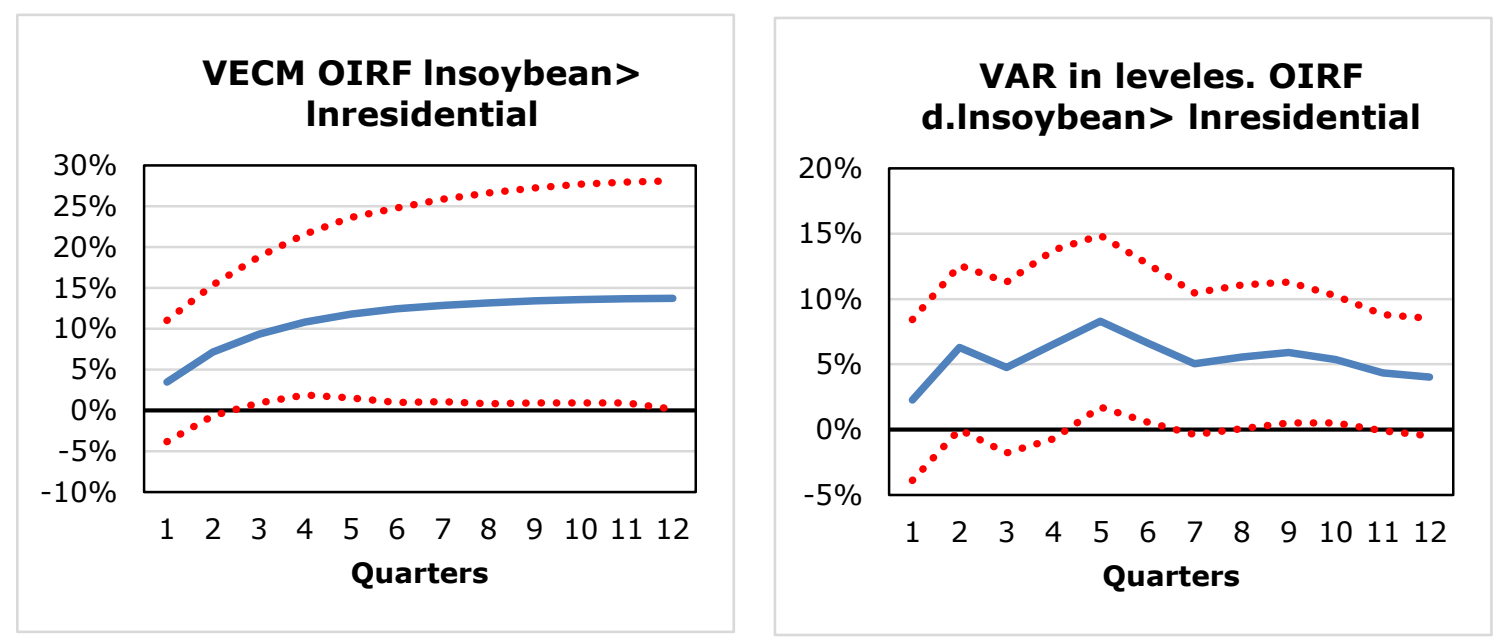

Notes:. a- The restricted VEC models contain one constraint that reflects the weak exogeneity of soybean prices (alpha=0) in the error correction term. Its VAR representation is a VAR(2). Estimation procedure: two stage. First: Johansen approach. Second: EGLS. $95 \%$ Hall percentile bootstrap confidence intervals based on 500 bootstrap replications. b- VAR(4) $95 \% \mathrm{Cl}$ bootstrapped standard errors. In both models, the covariates are: d.In(soybean price), d.In(GDP) and d.In(cost).

Introducing the real interest rate to the bivariate model, we should take into account that, according to unit root tests, it is not clear whether real interest rate is $\mathrm{I}(0)$ or $\mathrm{I}(1)$, and ZA test gives evidence of stationary allowing a break. Following with a skeptic criterion, I estimate different models assuming those different possibilities.

Firstly, if real interest rate and residential building are both $\mathrm{I}(1)$, a Johansen cointegration test is performed, and gives evidence of one cointegration rank. The VECM model estimated does not give evidence of an effect. If real interest rate is I(0), there is not an effect either. Then, using the detrended or filtered series of real interest rate -after applying a polynomial trend with a structural change- although the estimation is positive, is not statistically significative. Finally, it could be argued that real interest rate does not depend of soybean prices $^{9}$, so another restriction to the system is added and results are displayed in graph (d). The effect reaches $6.6 \%$ after six months and is almost statistically significative.

\footnotetext{
${ }^{9}$ It is beyond the scope of this paper to discuss the exogeneity or not of real interest rate.
} 
Figure 4: OIRF introducing real interest rate as a covariate

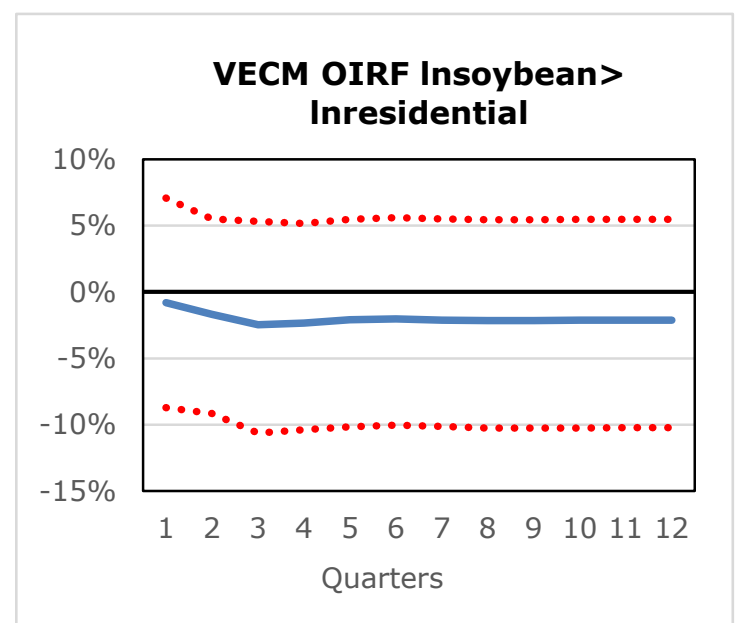

(a)

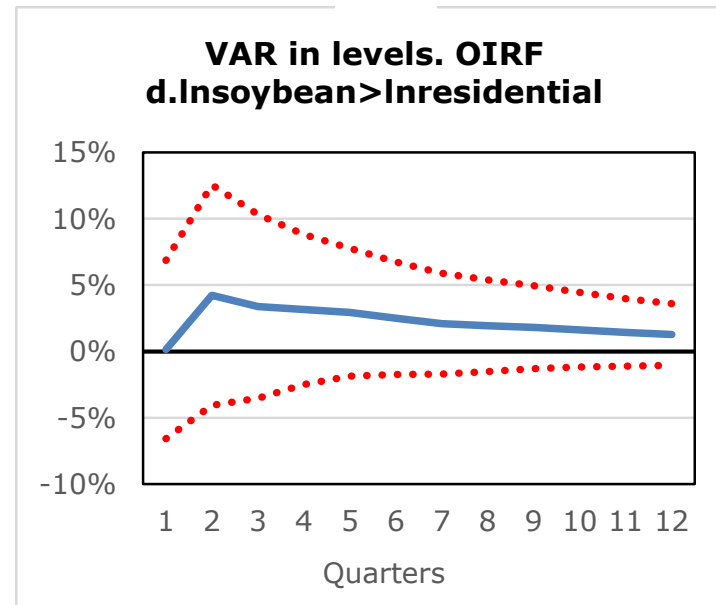

(c)

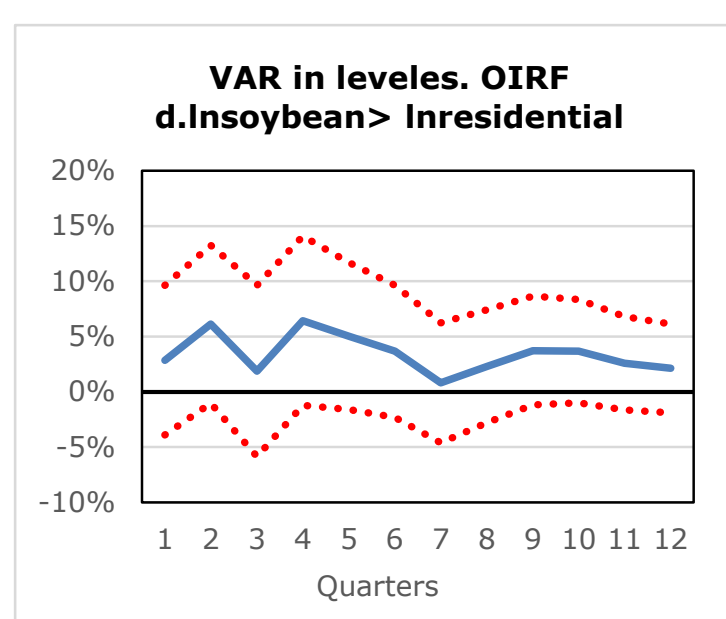

(b)

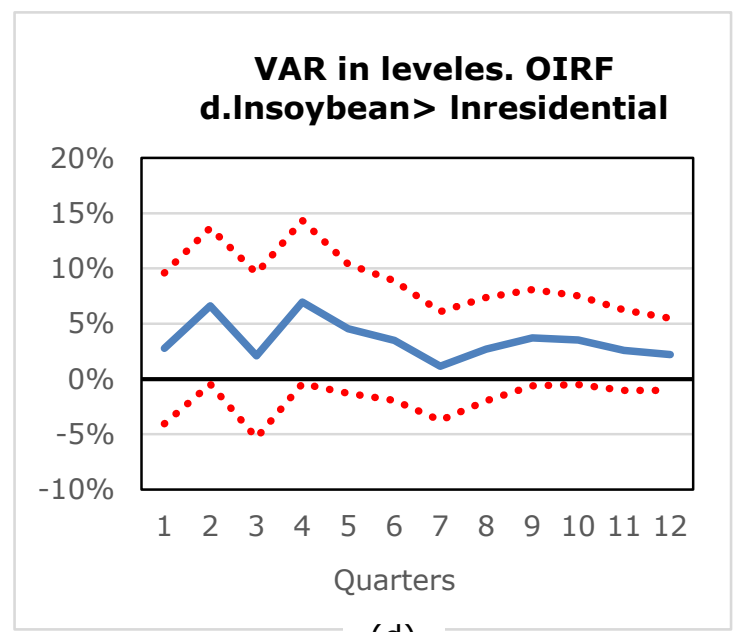

(d)

Even though the effect has vanished, it is worth noting that the sample has been reduced since the real rate series starts at 1999. Also, the latter series could also be modelled in many alternative ways that could also be tested but are beyond the scope of this paper. ${ }^{10}$ Finally, as it can be seen in the estimation results in the Appendix, the sign of the lagged values of real interest rate parameters are negative, as expected.

The last but not the least issue is the replacement of the residential permits series by building permits. As in the real interest rate series case, is not clear the integration order and whether the series is stationary after taking into consideration one structural break. Again, if it is $\mathrm{I}(1)$ a Johansen cointegration test is performed for the bivariate and full model and a VECM is estimated if there is at least one cointegration vector. On the contrary, if we assume the series is stationary, a VAR in levels is calculated.

\footnotetext{
${ }^{10}$ For example: a better modeling of structural breaks, or the introduction of outliers, or even the inclusion of more restrictions on the VAR system.
} 
Finally, the detrended series of building permits is used and a VAR in levels is estimated as well.

According to orthogonal impulse response function estimation, the effect of a soybean price shock would be statistically significative in the VECM bivariate model and in the VAR in levels full model only in the fifth quarter. The fast convergence to zero in the bivariate VAR system with the detrended series is not surprising, since it has short memory and the beta parameter that measures the effect of lagged values of soybean prices is almost zero. Moreover, the interpretation of the detrended series is troublesome, since although stationary, it is a "cleaned up" series from its polynomial trend, a trend that could be potentially affected by other variables that are not in the system.

Figure 5: Bivariate model with building permits

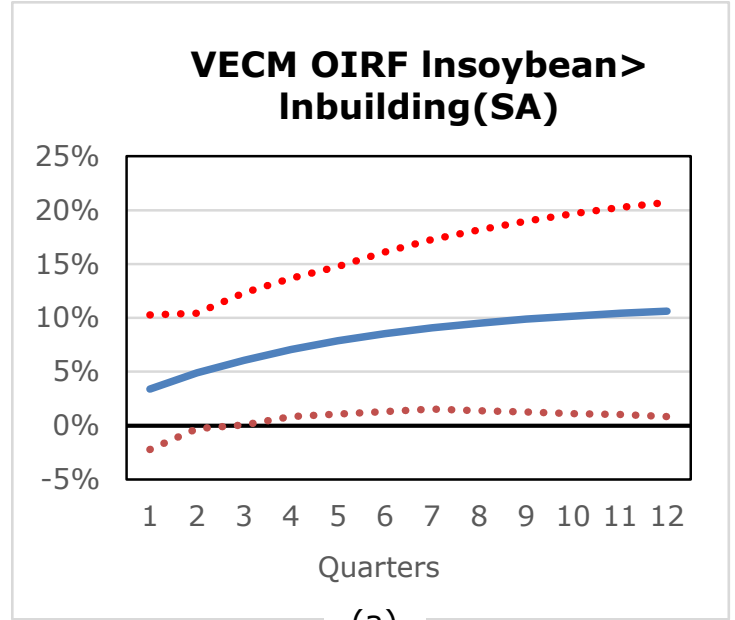

(a)

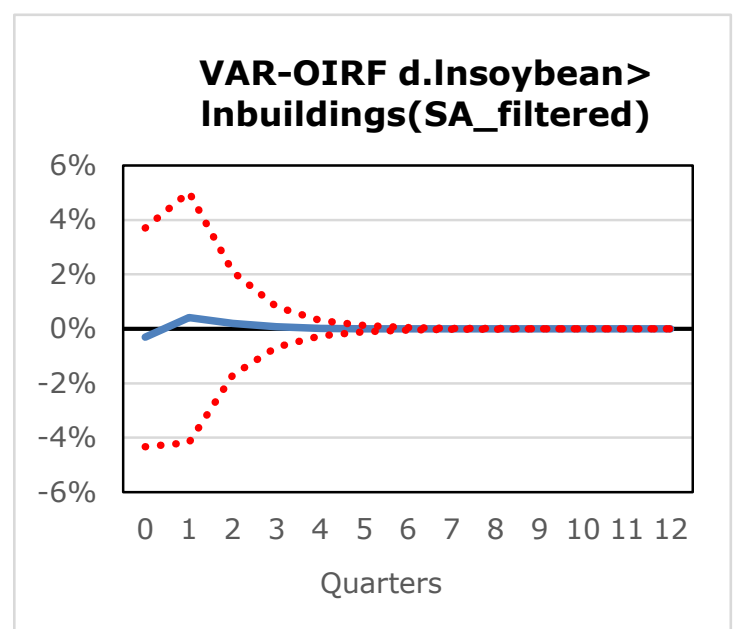

(c)

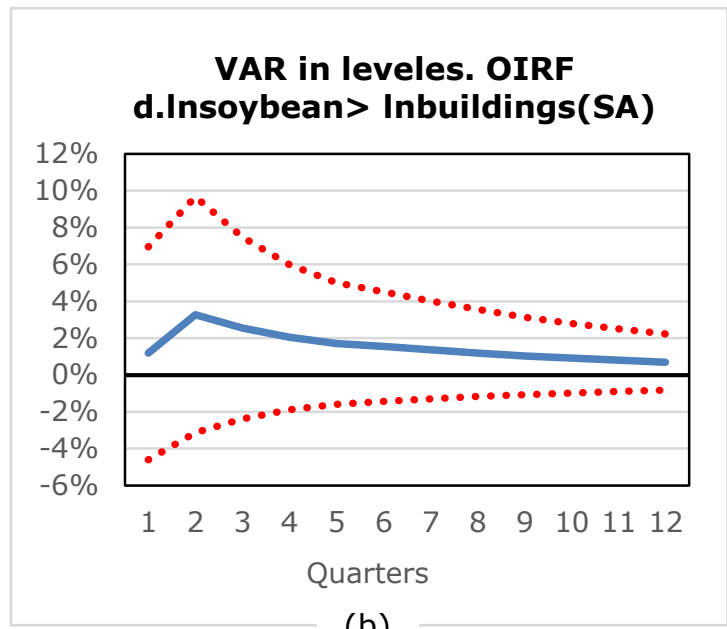

(b)

Notes:. a- The restricted VEC models contain one constraint that reflects the weak exogeneity of soybean prices (alpha $=0$ ) in the error correction term. Its VAR representation is a $\operatorname{VAR}(2)$ Estimation procedure: two stage. First: Johansen approach. Second: EGLS. 95\% Hall percentile bootstrap confidence intervals based on 500 bootstrap replications. b- $\operatorname{VAR}(2)$ c- $\operatorname{VAR}(1)$ with the detrended series of building permits. In Models b-c $95 \% \mathrm{Cl}$ bootstrapped standard errors 
Comparing bivariate VEC models for the first six quarters, the permanent shock in soybean prices would provoke a larger but shorter effect into residential permits than into buildings. Looking at Table 3 it takes too much time in the building series to reach the same effect as in buildings, and then it lasts to decay (it turns to zero after the third year). In the context of the hypothesis of the agrarian surplus financing the construction activity this result is reasonable, since building series includes other types of construction that a farmer is not directly interested to invest in. In addition, contrasting full models specifications for both construction series, the effect in VAR in levels for residential permits is also larger.

Setting side by side bivariate and full models for building permits, it is difficult to explain how the effect dissapears from the bivariate to the full model VEC, and it happens the opposite in the VAR in levels.

Figure 6: Full model with building permits

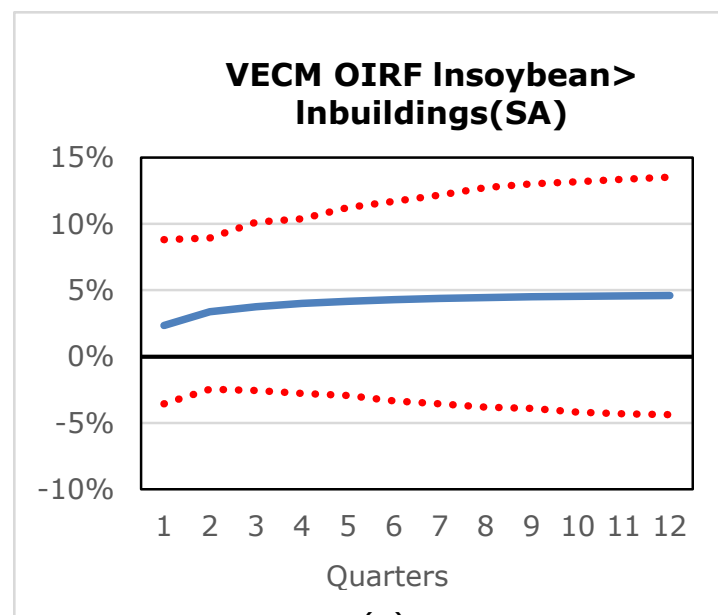

(a)

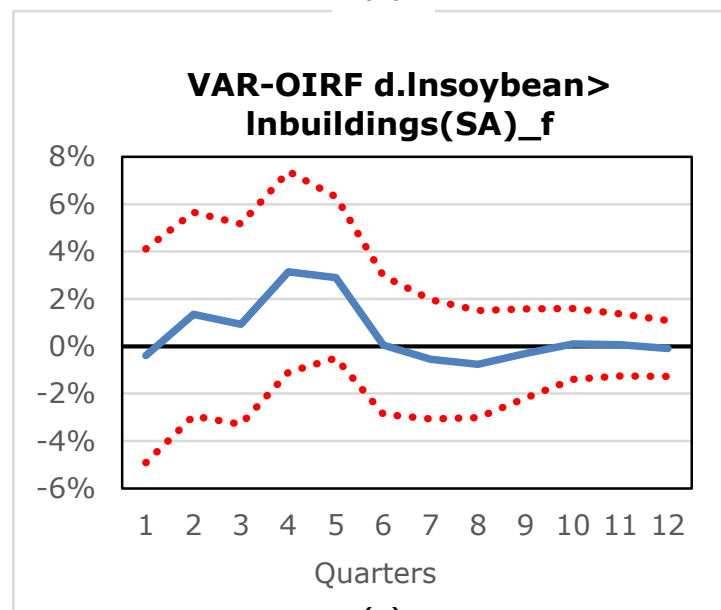

(c)

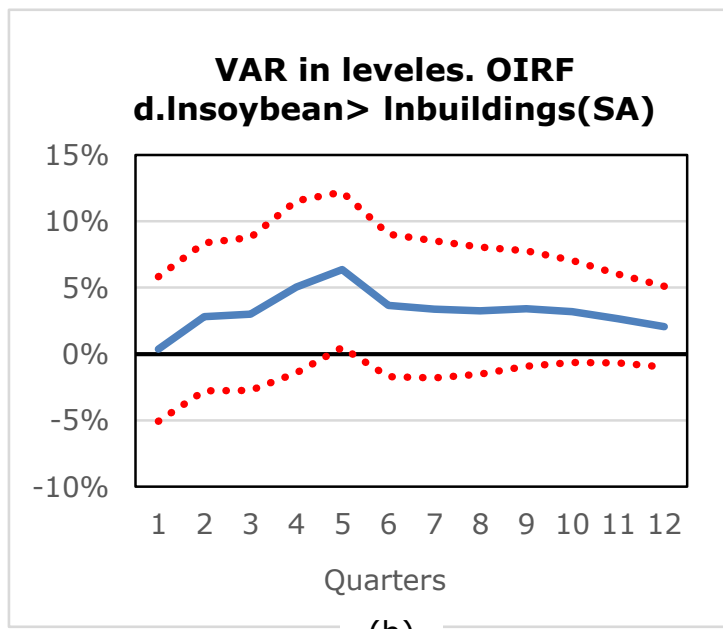

(b)

Notes:- a- The restricted VEC models contain one constraint that reflects the weak exogeneity of soybean prices $(a l p h a=0)$ in the error correction term. Its VAR representation is a $\operatorname{VAR}(2)$. Estimation procedure: two stage. First: Johansen approach. Second: EGLS. 95\% Hall percentile bootstrap confidence intervals based on 500 bootstrap replications. b- VAR(4) c- VAR(1) with the detrended series of building permits. In Models b and c $95 \% \mathrm{Cl}$ bootstrapped standard errors. 
Table 3: Summary of model results

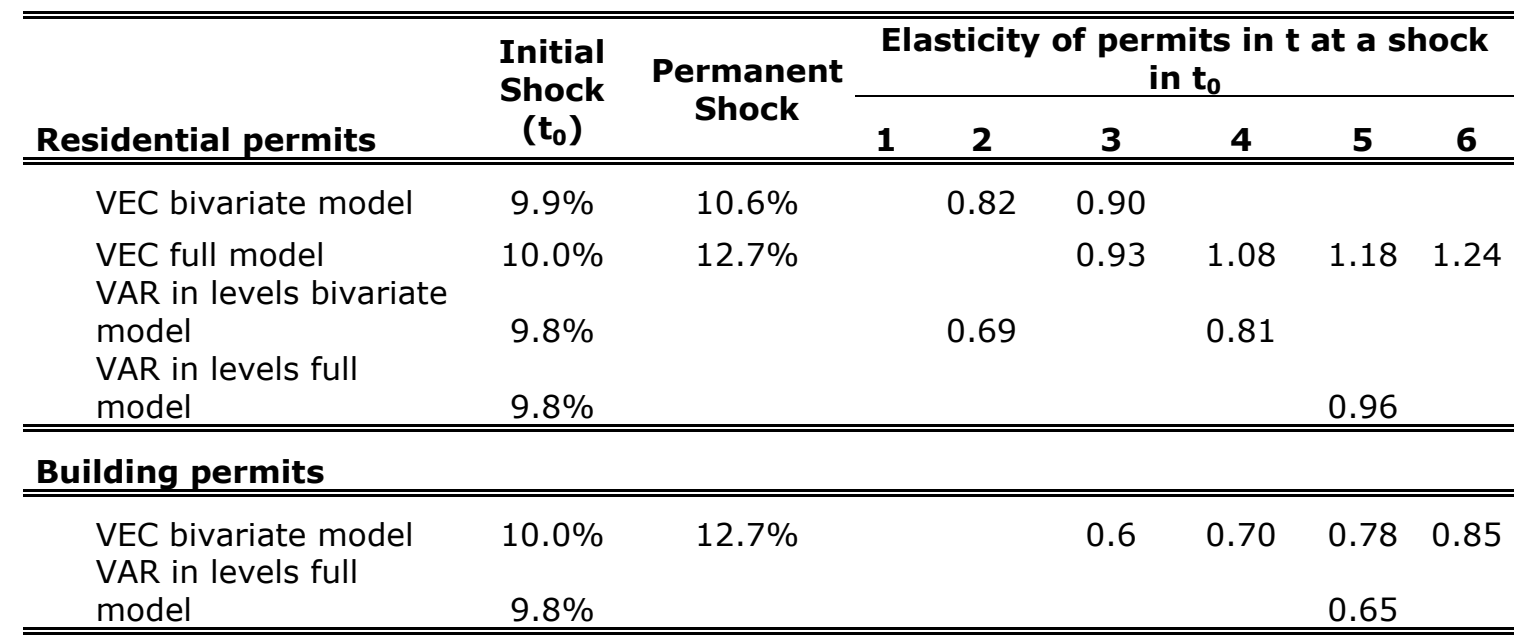

Note: Only effects that are statistically significative are shown. For example, at the first quarter there is not any effect. VAR in levels means that only the permits variable is in levels. The initial shock is the impulse in soybean prices at quarter $=0$. In VEC models, because of the recursive system the shock reaches a higher level. Elasticity is calculated as the ratio of percentage variation of residential (or building) permits in $t=(1-6)$ and initial shock. Both variations come from OIRF.

\section{Conclusion}

In this paper, the plausible effect of soybean prices into the building activity of Rosario is studied using VAR methodology and orthogonal impulse response function assuming the weak exogeneity of the oilseed price. Different unit root tests are performed into the series in order to check their stationarity. As their results are not conclusive, different models are estimated based on different assumptions of the true characteristic of the series. Once the bivariate model is estimated as a benchmark, different robustness checks are performed.

On the one hand, results for residential permits are robust for bivariate and full model. VEC models give account for a permanent effect in the full model specification, and a transitory effect in bivariate one. This result is theoretically reasonable under Friedman income hypothesis: a permanent shock in prices affects permanently consumption and therefore GDP, pushing building in last term. In addition, VAR models support a transitory effect. The time path of the effect would be specially along the first year the elasticity ranges from 0.69 to $0.96-$. Introducing real interest rate, the effect disappears possibly due to less observations and different time span, or poor modelling.

On the other hand, estimation results show different degree of robustness for building permits. Despite this, a brief conclusion can be made: residential permits shows larger point estimations than building permits. This seems reasonable in the context of the hypothesis of farmers financing new residential buildings instead of health, education or commercial buildings. 
In conclusion -and beyond model specification- data are acquainting for a plausible positive and transitory effect of soybean prices into residential activity in Rosario for the period 1994-2018. This possitive effect is in concordance with the results obtained by Grimes and Hyland (2013) for New Zelaland. Nevertheless, this paper has some limitations and a word of caution should be made. Although this paper is coherent with the methodology employed, other time series techiniques could also be tested in order to improve models and accurate results (e.g.working with outliers or modelling structural breaks).

Further research should be taken in order to shed more light on the relationship between the surplus in the agrarian sector and construction activity, reflected here beteween soybean prices and construction in Rosario. Some extesions of this paper could be using panel data with statistics of construction in cities that depend of soybeans and those which do not. Also, threshold VAR models could be estimated in order to inquire if there is a minimum price from which a effect could be detected. This would be very useful in the Argentinean debate for export taxes. 


\section{References}

Bai, Jushan (1997). "Estimating multiple breaks one at a time". Econometric Theory, Volume 13, Issue 3 June 1997, pp. 315-352

Bai, Jushan and Perron, Pierre (1998). "Estimating and testing linear models with multiple structural changes". Econometrica, Vol 66, No.1 (Jan 1998), 47-78.

Bebczuk, Ricardo; Garegnani, María Lorena (2012). "Real State as Housing and as Financial Investment: A First Assessment for Argentina". Documento de Trabajo N 95. November 2012. Universidad Nacional de La Plata (UNLP).

Bus, Ana y Nicolini, José (2010). "Medición de la renta diferencial agrícola en Argentina en 1986-2008". Anales de la Asociación Argentina de Economía Política (AAEA). XLV Reunión Anual. November 2010

Céspedes, L.F., and Velasco A (2012). "Macroeconomic Performance During Commodity Price Booms and Busts", NBER Working Paper 18569, Issued in November 2012. National Bureau of Economic Research, Cambridge, MA.

Compañía Argentina de Tierras. Website: http://www.cadetierras.com.ar/valores-yestadisticas/valor-alquileres-agricolas/

Elliott, G. R., T. J. Rothenberg, and J. H. Stock (1996). "Efficient tests for an autoregressive unit root". Econometrica Vol 64, N 4 (July 1996), pp.813-836.

Enders, Walter (2004). Applied Econometric Time Series. Ed. John Wiley \& Sons. Second Edition.

Evenett, S. J., \& Jenny, F. (Eds.). (2012). Trade, competition, and the pricing of commodities. Centre for Economic Policy Research.

Friedman, M. (1957). The permanent income hypothesis. In $A$ theory of the consumption function (pp. 20-37). Princeton University Press.

Grimes, G. \& Hyland, S. (With Coleman, A., Kerr, J. and Collier, A.) (2013). "A New Zealand Regional Housing Model", Working Paper 13-02. Wellington: Motu Economic and Public Policy Research.

Hamilton J. D. (1994). Time Series Analysis. New Jersey: Princeton University Press.

Koitsiwe, Kegomoditswe and Adachi, Tsuyoshi (2015). "Australia mining boom and Dutch disease: analysis using VAR method". Procedia Economics and Finance 30 (2015) 401-408. 3rd Economics \& Finance Conference, Rome, Italy, April 14-17, 2015 and 4th Economics \& Finance Conference, London, UK, August 25-28, 2015

Lapelle, Hernán; López Asensio, Guillermo; Woelflin, María Lidia (2011) "El sector construcción-inmobiliario a una década de la crisis 2001". Decimosextas Jornadas de "Investigación en la Facultad" de Ciencias Económicas y Estadística (UNR), 2011

Lütkepohl, H., Saikkonen, P., \& Trenkler, C. (2001). Maximum eigenvalue versus trace tests for the cointegrating rank of a VAR process. The Econometrics Journal, 4(2), 287310

Lüktepohl, H. and Kratzig, Markus (2005) "VECM analysis in JMulTi". Available http://www.jmulti.de/download/help/vecm.pdf 
Lüktepohl, Helmut (2005) New Introduction to multiple time series analysis. Springer

Muñoz, Ercio (2013) "Precio de materias primas y spread soberano en economías emergentes, ¿importa la concentración de las exportaciones?". Working paper n684, 2013. Central Bank of Chile.

Ng, S., and P. Perron (1995). "Unit root tests in ARMA models with data-dependent methods for the selection of the truncation lag". Journal of the American Statistical Association Vol 90, N 429 (March 1995), pp: 268-281

Pedersen, Michael (2015). "The Impact of Commodity Price Shocks in a Major Producing Economy". The Case of Copper and Chile. Working Paper N753, 2015. Central Bank of Chile.

Phillips, P. C. B., and P. Perron (1988). "Testing for a unit root in time series regression". Biometrika (1988),75,2, pp.: 335-346

StataCorp, 2017. Stata: Release 15. Stata Glossary and Index. Stata press.

Sing, Michael; Edwards, D.J.; Liu, Henry J. X. and Love, P. (2015). "Forecasting Private-Sector Construction Works: VAR Model Using Economic Indicators". Journal of Construction Engineering and Management. Vol 141 Issue 11-November 2015

Zivot, E. and Andrews, D. (1992). "Further evidence on the Great Crash, the oil price shock, and the unit-root hypothesis". Journal of Business and Economic Statistics July 1992, Volume 10, N³, pp. 251-70.

\section{Annex}

\section{Appendix A: Data Appendix}

Building permits: it includes the authorized covered area for all types of buildings: residential, commercial, and others. In addition, it includes new buildings and reforms to the existing ones. Source: Municipality of Rosario.

Residential permits: it is a subset of building permits and includes only new residential buildings. Source: Municipality of Rosario.

Real GDP (base 2004=100): Real Gross Domestic Product. The original series starts in 2004. In order to rebuild the series from 1994 to 2004, the quarter percentage variation of real GDP (base $1993=100$ ) was applied. Source: own elaboration based on INDEC.

Nominal interest rate BADLAR: The Buenos Aires Deposits of Large Rate (BADLAR) is calculated by the Central Bank taking into account a sample of banks in Capital Federal and Gran Buenos Aires. Includes deposits from 30 to 35 days of more than one million Argentinian pesos. Source: Central Bank of Argentina. 
Real interest rate: It is the BADLAR rate deflated by a composed price index. It begins with the National Price Index and then uses a mixture of San Luis and Capital Federal consumer prices indexes.

Building costs in dollars: It is the Construction Cost Index (base 1993=100) divided the official exchange rate in Argentina. The series tries to reflect the cost of building in current dollars. Source: own elaboration based on INDEC and Central Bank of Argentina.

\section{Appendix B: Figures}

Figure B1: Real GDP Seasonally adjusted

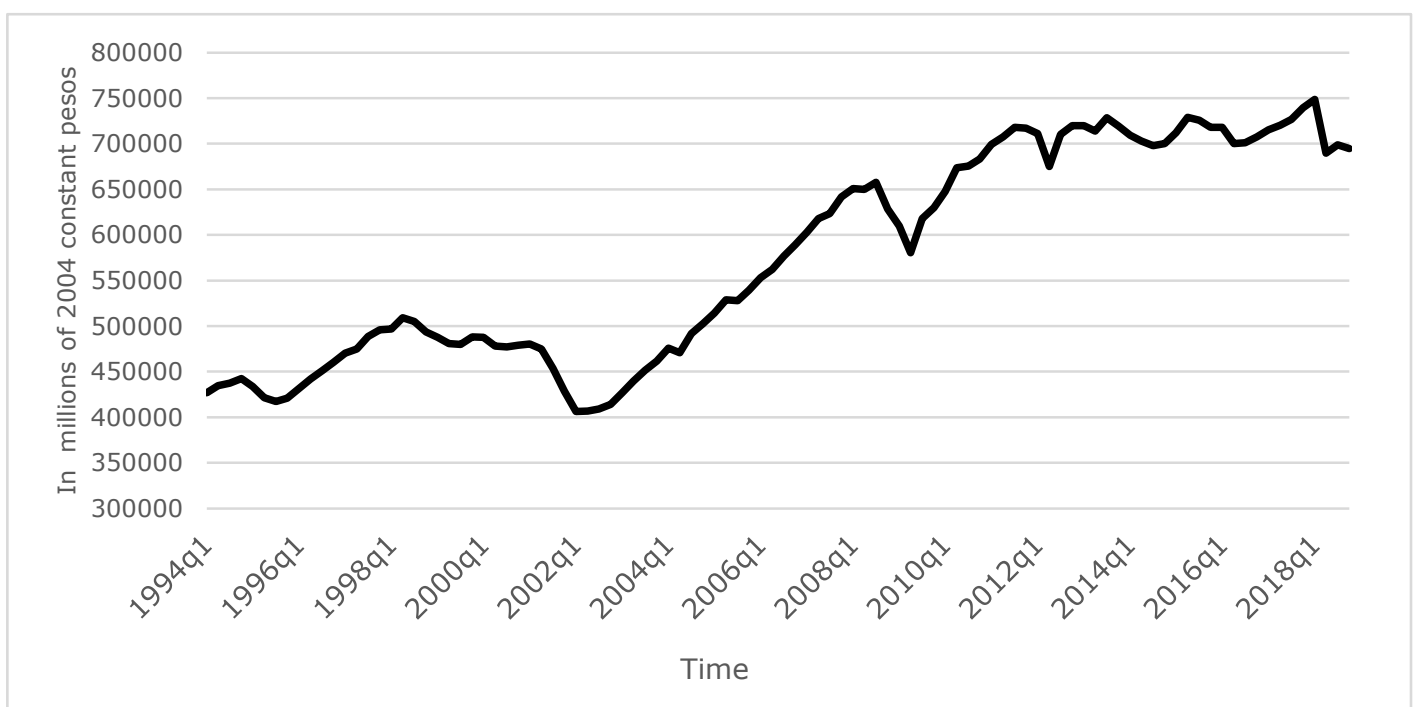

Source: Own elaboration based on INDEC

Figure B2: Building costs in dollars

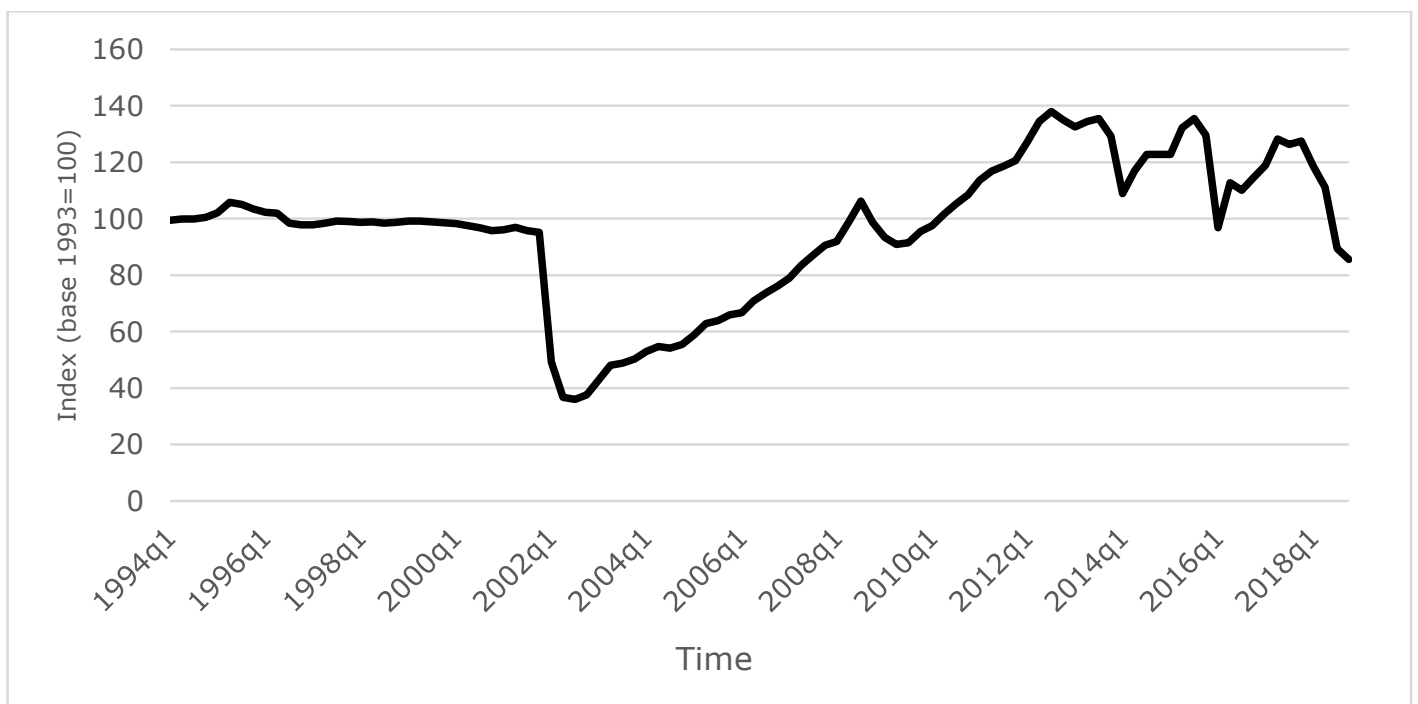

Source: Own elaboration based on INDEC and Central Bank of Argentina. 
Figure B3: Building permits in Rosario (Seasonally adjusted)

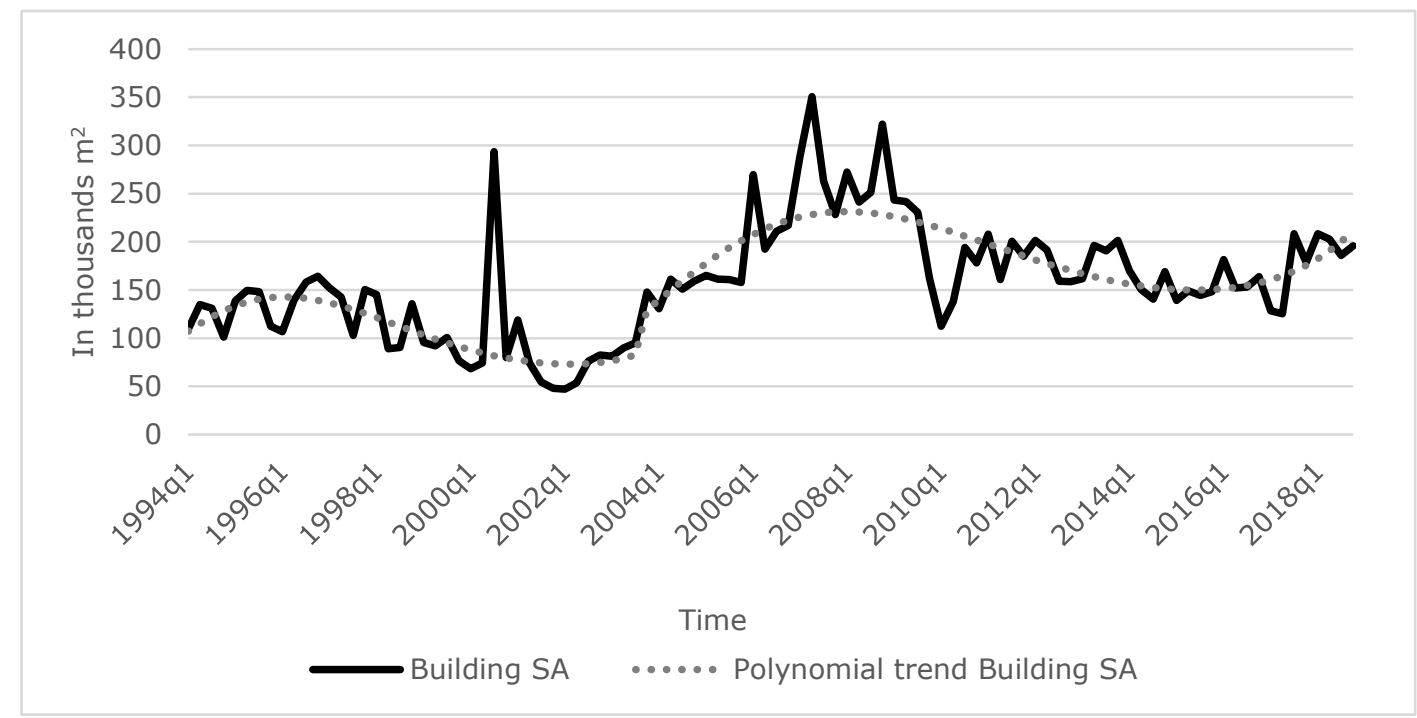

Source: Own elaboration based on Municipality of Rosario

Figure B4: Real interest rate (\%)

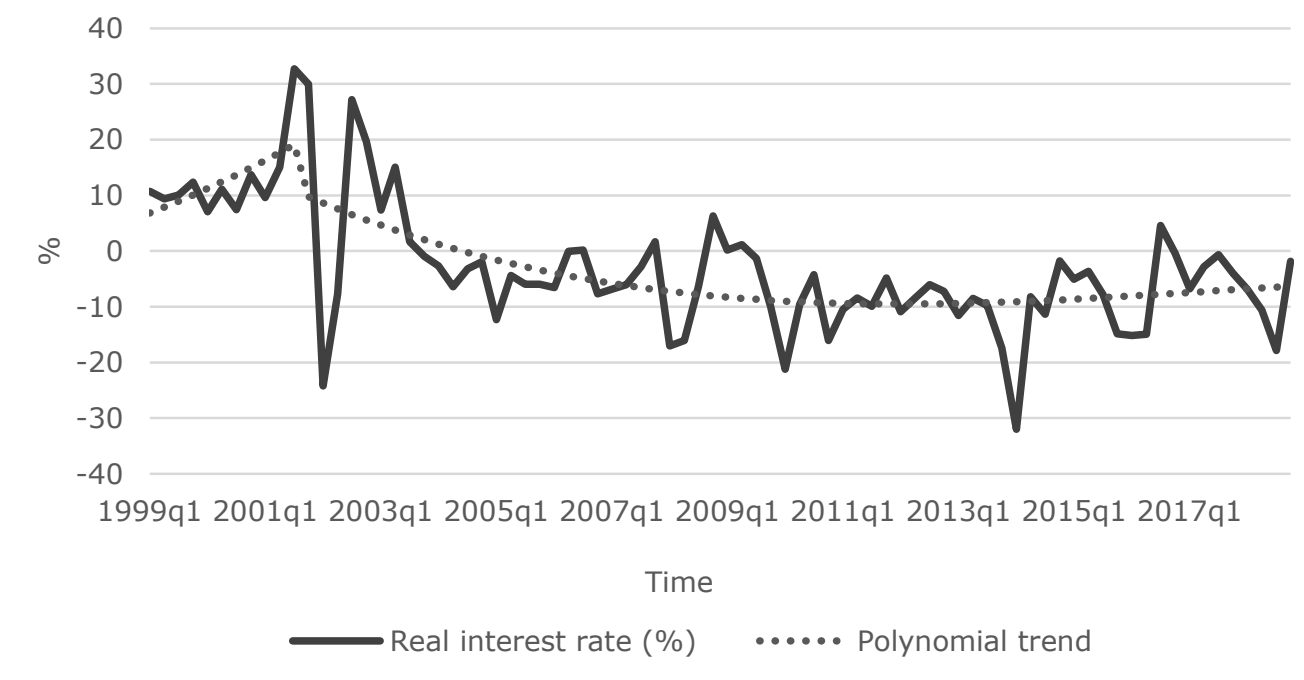

Source: Own elaboration based on Central Bank of Argentina and the combination of San Luis and Capital Federal price indexes. 


\section{Appendix C: Information Criteria and Johansen Cointegration Tests}

Table C1: Bivariate and full model for Residential

Selection order criteria

\begin{tabular}{lcccccccc}
\hline \multicolumn{3}{l}{$\begin{array}{l}\text { Sample: } 1995 q 1- \\
\text { 2018q4 }\end{array}$} & \multicolumn{10}{c}{ Number of observations: 96 } \\
\hline \hline lag & LL & LR & df & p & FPE & AIC & HQIC & SBIC \\
\hline \hline 0 & -90.5975 & & & & 0.023597 & 1.92912 & 1.95071 & 1.98254 \\
1 & 66.8017 & 314.8 & 4 & 0 & 0.00096 & -1.2667 & $-1.20192^{*}$ & $-1.10643^{*}$ \\
2 & 71.5885 & $9.5736 *$ & 4 & 0.048 & 0.00095 & -1.28309 & -1.17512 & -1.01597 \\
3 & 76.0698 & 8.9625 & 4 & 0.062 & $0.00094^{*}$ & $-1.29312^{*}$ & -1.14196 & -.919153 \\
4 & 78.5441 & 4.9485 & 4 & 0.293 & 0.000972 & -1.26133 & -1.06698 & -.780519 \\
\hline \hline
\end{tabular}

Endogenous: Insoybean Inresidential

Exogenous: Constant

Selection order criteria

Sample: 1995q1-

2018q4 Number of observations: 96

\begin{tabular}{ccccccccc}
\hline \hline lag & LL & LR & df & P & FPE & AIC & HQIC & SBIC \\
\hline \hline 0 & -11.7469 & & & & 0.000016 & 0.32806 & 0.37125 & .434909 \\
1 & 402.34 & 828.17 & 16 & 0 & $4.1 \mathrm{E}-09$ & -7.96541 & $-7.74946 *$ & $-7.43117 *$ \\
2 & 424.733 & 44.786 & 16 & 0 & $3.6 \mathrm{E}-09 *$ & $-8.0986 *$ & -7.70989 & -7.13697 \\
3 & 432.767 & 16.069 & 16 & 0.448 & $4.2 \mathrm{E}-09$ & -7.93265 & -7.37118 & -6.54363 \\
4 & 449.332 & $33.129 *$ & 16 & 0.007 & $4.2 \mathrm{E}-09$ & -7.94441 & -7.21018 & -6.128 \\
\hline \hline
\end{tabular}

Endogenous: Insoybean InGDP Incost Inresidential

Exogenous: Constant

\section{Johansen cointegration test}

\begin{tabular}{|c|c|c|c|c|c|c|c|c|c|c|}
\hline \multicolumn{3}{|c|}{ Variables } & \multicolumn{3}{|c|}{ Insoybean Inresidential } & \multicolumn{5}{|c|}{ Insoybean InGDP Incost Inresidential } \\
\hline lag & $\begin{array}{l}\text { Max } \\
\text { rank }\end{array}$ & $\begin{array}{c}\text { Trace } \\
\text { stat }\end{array}$ & $\begin{array}{c}5 \% \\
\text { critical } \\
\text { value }\end{array}$ & $\begin{array}{c}\text { Max } \\
\text { eigenvalue } \\
\text { stat }\end{array}$ & $\begin{array}{c}5 \% \\
\text { critical } \\
\text { value }\end{array}$ & $\begin{array}{l}\text { Max } \\
\text { rank }\end{array}$ & $\begin{array}{c}\text { Trace } \\
\text { stat }\end{array}$ & $\begin{array}{c}5 \% \\
\text { critical } \\
\text { value }\end{array}$ & $\begin{array}{c}\text { Max } \\
\text { eigenvalue } \\
\text { stat }\end{array}$ & $\begin{array}{c}5 \% \\
\text { critical } \\
\text { value }\end{array}$ \\
\hline \multirow{5}{*}{1} & 0 & 19.21 & 15.41 & 17.32 & 14.07 & 0 & 52.84 & 47.21 & 24.79 & 27.07 \\
\hline & 1 & $1.88 *$ & 3.76 & 1.88 & 3.76 & 1 & $28.04 *$ & 29.68 & 18.92 & 20.97 \\
\hline & 2 & & & & & 2 & 9.12 & 15.41 & 6.98 & 14.07 \\
\hline & & & & & & 3 & 2.13 & 3.76 & 2.13 & 3.76 \\
\hline & & & & & & 4 & & & & \\
\hline
\end{tabular}

Note: * means the rank chosen. In the trace statistic the null hypothesis is that there are no more than $r$ cointegrating relations. In the maximum eigenvalue statistic, the null is that there are $r$ relations against the alternative there are $r+1$. 
Table C2: Bivariate and full model for Building permits

Selection order criteria

\begin{tabular}{ccccccccc}
\hline \hline \multicolumn{2}{l}{ Sample: 1995q1-2018q4 } & & \multicolumn{5}{c}{ Number of observations: 96 } \\
\hline \hline lag & LL & LR & df & p & FPE & AIC & HQIC & SBIC \\
\hline \hline 0 & -71.0571 & & & & 0.015706 & 1.52202 & 1.54362 & 1.57545 \\
1 & 78.3509 & 298.82 & 4 & 0 & 0.000759 & -1.50731 & $-1.44253^{*}$ & $-1.34704^{*}$ \\
2 & 84.409 & $12.116^{*}$ & 4 & 0.017 & $.000728^{*}$ & $-1.55019^{*}$ & -1.44221 & -1.28307 \\
3 & 86.2761 & 3.7341 & 4 & 0.443 & 0.000761 & -1.50575 & -1.35459 & -1.13178 \\
4 & 88.1433 & 3.7345 & 4 & 0.443 & 0.000796 & -1.46132 & -1.26697 & -0.980504 \\
\hline \hline
\end{tabular}

Endogenous: Insoybean Inbuilding(SA)

Exogenous: Constant

Selection order criteria

\begin{tabular}{|c|c|c|c|c|c|c|c|c|c|c|c|c|}
\hline \multicolumn{6}{|c|}{ Sample: 1995q1-2018q4 } & \multicolumn{7}{|c|}{ Number of observations: 96} \\
\hline lag & \multicolumn{2}{|c|}{$\mathrm{LL}$} & LR & $\mathrm{df}$ & $\mathrm{p}$ & \multicolumn{2}{|l|}{ FPE } & AIC & \multicolumn{2}{|c|}{ HQIC } & \multicolumn{2}{|c|}{ SBIC } \\
\hline 0 & \multicolumn{2}{|c|}{3.43214} & & & & \multicolumn{2}{|c|}{0.000012} & 0.01183 & \multicolumn{2}{|c|}{0.05502} & \multicolumn{2}{|c|}{0.118678} \\
\hline 1 & \multicolumn{2}{|c|}{414.652} & 822.44 & 16 & 0 & \multicolumn{2}{|c|}{$3.2 \mathrm{E}-09$} & -8.22192 & \multicolumn{2}{|c|}{$-8.00597 *$} & \multicolumn{2}{|c|}{$-7.68768 *$} \\
\hline 2 & \multicolumn{2}{|c|}{437.241} & 45.178 & 16 & 0 & \multicolumn{2}{|c|}{$2.8 \mathrm{E}-09 *$} & $-8.35919 *$ & \multicolumn{2}{|c|}{-7.97049} & \multicolumn{2}{|c|}{-7.39756} \\
\hline 3 & \multicolumn{2}{|c|}{442.878} & 11.273 & 16 & 0.792 & \multicolumn{2}{|c|}{ 3.4E-09 } & -8.14329 & \multicolumn{2}{|c|}{-7.58183} & \multicolumn{2}{|c|}{-6.75427} \\
\hline 4 & \multicolumn{2}{|c|}{458.444} & $31.132 *$ & 16 & 0.013 & \multicolumn{2}{|c|}{$3.5 \mathrm{E}-09$} & -8.13425 & \multicolumn{2}{|c|}{-7.40003} & \multicolumn{2}{|c|}{-6.31784} \\
\hline \multicolumn{13}{|c|}{$\begin{array}{l}\text { Endogenous: Insoybean InGDP Incost Inbuilding(SA) } \\
\text { Exogenous: Constant }\end{array}$} \\
\hline \multicolumn{13}{|c|}{ Johansen cointegration test } \\
\hline \multicolumn{3}{|c|}{ Variables } & \multicolumn{4}{|c|}{ Insoybean Inbuilding(SA) } & \multicolumn{6}{|c|}{ Insoybean InGDP Incost Inbuilding(SA) } \\
\hline lag & $\begin{array}{l}\text { Max } \\
\text { rank }\end{array}$ & $\begin{array}{l}\text { Trac } \\
\text { stat }\end{array}$ & $\begin{array}{c}5 \% \\
\text { critical } \\
\text { value }\end{array}$ & $\begin{array}{r}N \\
\text { eiget } \\
S\end{array}$ & $\begin{array}{l}\text { Max } \\
\text { nvalue } \\
\text { tat }\end{array}$ & $\begin{array}{c}5 \% \\
\text { critical } \\
\text { value }\end{array}$ & $\begin{array}{l}\text { Max } \\
\text { rank }\end{array}$ & $\begin{array}{l}\text { Trace } \\
\text { stat }\end{array}$ & $\begin{array}{c}5 \% \\
\text { critical } \\
\text { value }\end{array}$ & $\begin{array}{r}M \\
\text { eigen } \\
\text { st }\end{array}$ & $\begin{array}{l}x \\
\text { alue } \\
t\end{array}$ & $\begin{array}{c}5 \% \\
\text { critical } \\
\text { value }\end{array}$ \\
\hline \multirow{5}{*}{1} & 0 & 22.6 & 15.41 & & 0.61 & 14.07 & 0 & 58.88 & 47.21 & 32 & & 27.07 \\
\hline & 1 & 2.03 & 3.76 & & .03 & 3.76 & 1 & $26.16^{*}$ & 29.68 & 17 & & 20.97 \\
\hline & \multirow[t]{3}{*}{2} & & & & & & 2 & 8.9 & 15.41 & 6. & & 14.07 \\
\hline & & & & & & & 3 & 2.02 & 3.76 & 2. & & 3.76 \\
\hline & & & & & & & 4 & & & & & \\
\hline
\end{tabular}

Note: * means the rank chosen. In the trace statistic the null hypothesis is that there are no more than $r$ cointegrating relations. In the maximum eigenvalue statistic, the null is that there are $r$ relations against the alternative there are $r+1$. 
Table C3: Bivariate model with real interest rate

\section{Selection order criteria}

\begin{tabular}{ccccccccc}
\hline \hline \multicolumn{3}{l}{ Sample: 2000q1-2018q4 } & & & \multicolumn{5}{c}{ Number of observations: 76 } \\
\hline \hline lag & LL & LR & df & p & FPE & AIC & HQIC & SBIC \\
\hline \hline 0 & -352.923 & & & & 2.34615 & 9.3664 & 9.40317 & 9.45841 \\
1 & -217.347 & 271.15 & 9 & 0 & 0.083921 & 6.03545 & $6.18253^{*}$ & $6.40346 *$ \\
2 & -206.362 & $21.97 *$ & 9 & 0.009 & $.079751^{*}$ & $5.98322^{*}$ & 6.2406 & 6.62723 \\
3 & -201.428 & 9.8682 & 9 & 0.361 & 0.089027 & 6.09021 & 6.4579 & 7.01024 \\
4 & -195.744 & 11.368 & 9 & 0.251 & 0.097689 & 6.17747 & 6.65547 & 7.37351 \\
\hline \hline
\end{tabular}

Endogenous: Insoybean $r$ Inresidential

Exogenous: Constant

Johansen cointegration test

\begin{tabular}{cccccc}
\hline \hline \multicolumn{2}{c}{ Variables } & \multicolumn{4}{c}{ Lnsoybean real interest rate Inresidential } \\
\hline \hline lag & Max rank & Trace stat & $\begin{array}{c}5 \% \text { critical } \\
\text { value }\end{array}$ & Max eigenvalue stat & 5\% critical value \\
\hline \hline & 0 & 53.13 & 29.68 & 39.28 & 20.97 \\
1 & 1 & $13.84^{*}$ & 15.41 & 11.4 & 14.07 \\
& 2 & 2.44 & 3.76 & 2.44 & 3.76 \\
\hline \hline
\end{tabular}

Note: * means the rank chosen. In the trace statistic the null hypothesis is that there are no more than $r$ cointegrating relations. In the maximum eigenvalue statistic, the null is that there are $r$ relations against the alternative there are $r+1$. 


\section{Appendix D: Estimation Results}

\section{Bivariate model}

\begin{tabular}{|c|c|c|c|c|c|}
\hline & & VAR in level & & VE & CM \\
\hline & Inresidential & Inbuilding(SA) & Inbuilding(SA)_f & d.Inresidential & $\begin{array}{c}\text { d. } \\
\text { Inbuilding(SA) }\end{array}$ \\
\hline L1.d.Insoybean & 0.21 & 0.06 & 0.05 & -0.04 & 0.02 \\
\hline & $(0.30)$ & $(0.25)$ & $(0.21)$ & $(0.29)$ & $(0.25)$ \\
\hline L2.d.Insoybean & 0.47 & 0.22 & & 0.38 & \\
\hline & $(0.30)$ & $(0.26)$ & & $(0.29)$ & \\
\hline L3.d.Insoybean & 0.04 & & & & \\
\hline & $(0.30)$ & & & & \\
\hline L4.d.Insoybean & $0.49 *$ & & & & \\
\hline & $(0.30)$ & & & & \\
\hline L1.y & $0.58 * * *$ & $0.53 * * *$ & $0.24 * *$ & $-0.24 * *$ & $-0.25 * *$ \\
\hline & $(0.10)$ & $(0.10)$ & $(0.10)$ & $(0.11)$ & $(0.10)$ \\
\hline L2.y & -0.01 & $0.30 * * *$ & & $-0.24 * *$ & \\
\hline & $(0.11)$ & $(0.10)$ & & $(0.10)$ & \\
\hline L3.y & 0.16 & & & & \\
\hline & $(0.12)$ & & & & \\
\hline L4.y & $0.19 * *$ & & & & \\
\hline & $(0.10)$ & & & & \\
\hline Constant & $0.41 *$ & $0.83 * *$ & -0.002 & $-0.52 * *$ & -0.05 \\
\hline & $(0.24)$ & $(0.33)$ & $(0.02)$ & $(0.30)$ & $(0.03)$ \\
\hline a yt-1 & & & & $0.20 *$ & $0.22 * * *$ \\
\hline & & & & $(0.10)$ & $(0.07)$ \\
\hline$\beta y t-1$ & & & & $-0.71 * * *$ & $-1.10 * * *$ \\
\hline & & & & $(0.18)$ & $(0.24)$ \\
\hline R-squared & 0.75 & 0.63 & 0.05 & & \\
\hline $\mathrm{N}$ & 95 & 97 & 98 & 97 & 98 \\
\hline $\begin{array}{l}\text { Autocorrelation } \\
\text { LM test-5 lags } \\
\text { (p-value) }\end{array}$ & 0.74 & 0.31 & 0.03 & 0.62 & 0.39 \\
\hline
\end{tabular}

Notes: L1.y means the lagged value of the output variable which is in each column. All models are stable. The diagnostic of no autocorrelation in residuals is tested with LM test. In modelling the filtered series of building permits, all VAR models residuals were autocorrelated, so a parsimonious model was chosen. In all models the weakly exogenous variable is soybean prices. Estimation procedure por VECM: two stage. First: Johansen approach. Second: EGLS. $\alpha$ is the adjustment parameter and $\beta$ is the parameter in the cointegrated equation. Standard errors in parentheses. ${ }^{* * *} p-v a l u e<0.01,{ }^{* *} p-$ value $<0.05$, ${ }^{*}$ p-value $<0.1$ 
Full model

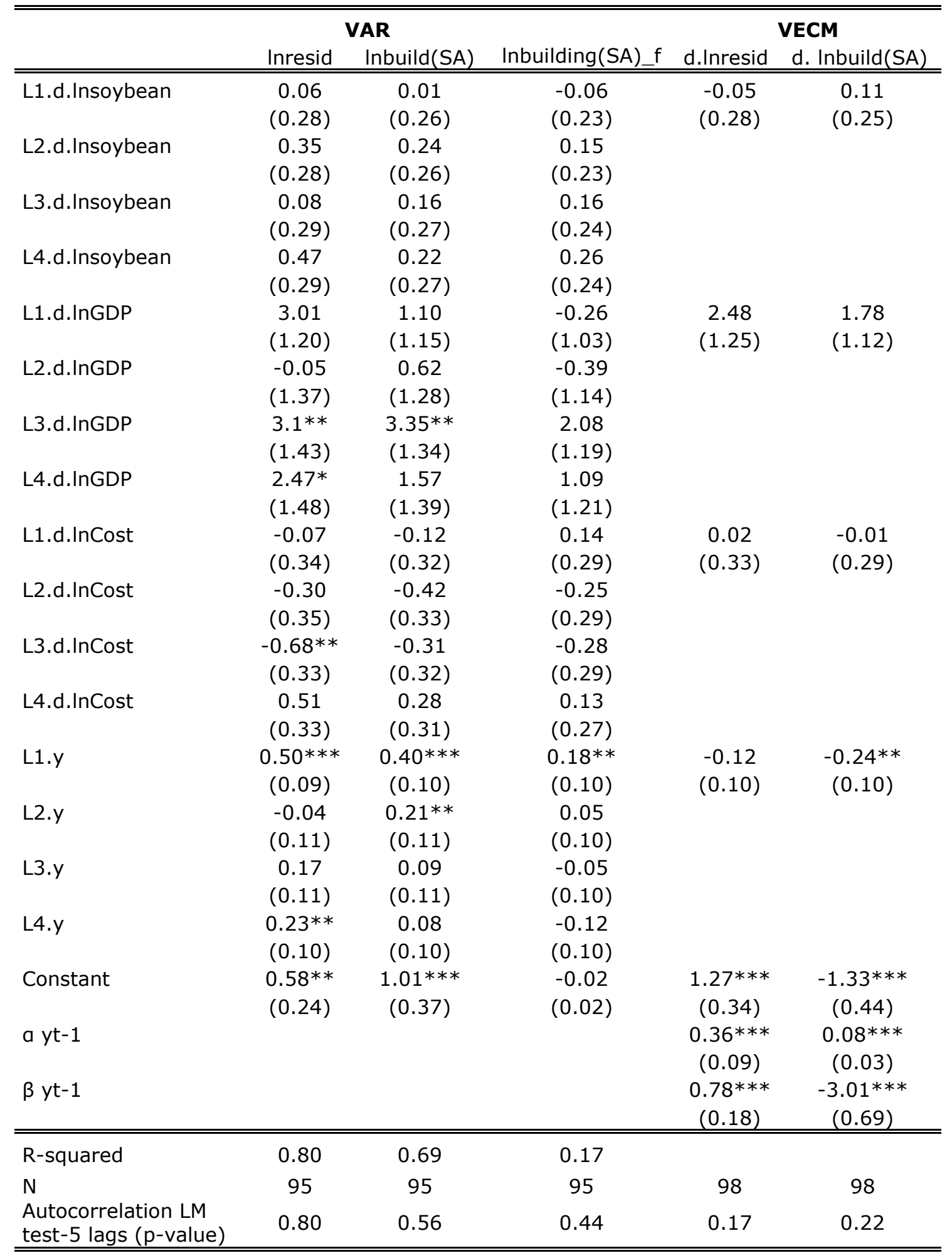

Notes: L1.y means the lagged value of the output variable which is in each column. All models are stable. The diagnostic of no autocorrelation in residuals is tested with LM test. In all models the weakly exogenous variable is soybean prices. Estimation procedure por VECM: two stage. First: Johansen approach. Second: EGLS. $\alpha$ is the adjustment parameter and $\beta$ is the parameter in the cointegrated equation. In the first VECM model, beta InGDP=0.23 and in the second is 1.65; For Incost, it is -0.42 and 0.57 respectively. Standard errors in parentheses. ${ }^{* \star *} p$-value $<0.01,{ }^{* *} p$-value $<0.05,{ }^{*} p$-value $<0.1$ 
Bivariate model with real interest rate

\begin{tabular}{|c|c|c|c|c|}
\hline & \multicolumn{3}{|c|}{ VAR } & \multirow{2}{*}{$\begin{array}{c}\text { VECM } \\
\text { d.Inresid } \\
\end{array}$} \\
\hline & Inresid & Inresid & Inresid & \\
\hline \multirow[t]{2}{*}{ L1.d.Insoybean } & 0.16 & -0.04 & 0.16 & 0.11 \\
\hline & $(0.29)$ & $(0.29)$ & $(0.29)$ & $(0.28)$ \\
\hline \multirow[t]{2}{*}{ L2.d.Insoybean } & 0.43 & 0.39 & 0.43 & \\
\hline & $(0.28)$ & $(0.30)$ & $(0.28)$ & \\
\hline \multirow[t]{2}{*}{ L3.d.Insoybean } & -0.28 & & -0.28 & \\
\hline & $(0.29)$ & & $(0.29)$ & \\
\hline \multirow{2}{*}{ L4.d.Insoybean } & 0.64 & & 0.64 & \\
\hline & $(0.29)$ & & $(0.29)$ & \\
\hline \multirow[t]{2}{*}{ L1.real interest } & $-0.006 *$ & & $-0.006 *$ & $0.009 * *$ \\
\hline & $(0.003)$ & & $(0.003)$ & $(0.004)$ \\
\hline \multirow[t]{2}{*}{ L2.real interest } & -0.001 & & -0.001 & \\
\hline & $(0.003)$ & & $(0.003)$ & \\
\hline \multirow[t]{2}{*}{ L3.real interest } & $-0.009 * *$ & & $-0.009 * *$ & \\
\hline & $(0.003)$ & & $(0.003)$ & \\
\hline \multirow[t]{2}{*}{ L4.real interest } & $0.007^{*}$ & & $0.007 *$ & \\
\hline & $(0.003)$ & & $(0.003)$ & \\
\hline \multirow[t]{2}{*}{ L1.real interest_f } & & -0.002 & & \\
\hline & & $(0.004)$ & & \\
\hline \multirow[t]{2}{*}{ L2.real interest_f } & & -0.005 & & \\
\hline & & $(0.004)$ & & \\
\hline \multirow[t]{2}{*}{ L1.y } & $0.59 * * *$ & $0.62 * * *$ & $0.59 * * *$ & $-0.27 * * *$ \\
\hline & $(0.11)$ & $(0.11)$ & $(0.11)$ & $(0.10)$ \\
\hline \multirow[t]{2}{*}{ L2.y } & 0.01 & $0.25 * *$ & 0.01 & \\
\hline & $(0.12)$ & $(0.10)$ & $(0.12)$ & \\
\hline \multirow[t]{2}{*}{ L3.y } & 0.08 & & 0.08 & \\
\hline & $(0.11)$ & & $(0.11)$ & \\
\hline \multirow[t]{2}{*}{ L4.y } & 0.11 & & 0.11 & \\
\hline & $(0.10)$ & & $(0.10)$ & \\
\hline \multirow[t]{2}{*}{ Constant } & $0.90 * *$ & $0.56 * *$ & $0.90 * *$ & $1.30 * * *$ \\
\hline & $(0.35)$ & $(0.24)$ & $(0.35)$ & $(0.05)$ \\
\hline \multirow[t]{2}{*}{ a yt-1 } & & & & $-0.16 * * *$ \\
\hline & & & & $(0.05)$ \\
\hline \multirow[t]{2}{*}{$\beta y t-1$} & & & & $0.59 * * *$ \\
\hline & & & & $(0.16)$ \\
\hline R-squared & 0.81 & 0.77 & 0.81 & \\
\hline$N$ & 76 & 78 & 76 & 78 \\
\hline $\begin{array}{l}\text { Autocorrelation LM test- } 5 \text { lags } \\
\text { (p-value) }\end{array}$ & 0.68 & 0.27 & 0.73 & 0.33 \\
\hline
\end{tabular}

Notes: L1.y means the lagged value of the output variable which is in each column. All models are stable. The diagnostic of no autocorrelation in residuals is tested with LM test. In all models the weakly exogenous variable is soybean prices, except the third model where real rate is also. Estimation procedure por VECM: two stage. First: Johansen approach. Second: EGLS. $\alpha$ is the adjustment parameter and $\beta$ is the parameter in the cointegrated equation. In the first VECM model, beta real rate $=0.08$. In the VAR representation Inresidential $=-0.07^{\star}$ soy $_{t-1}-0.09^{*}$ soy $_{t-2}-0.004 r_{t-1}-0.009 r_{t-2}+0.63^{\star} r^{-} s_{t-1}+0.27 r^{-2} s_{t-2}$ Standard errors in $\quad{ }^{* * *} p$-value $<0.01, \quad{ }^{* *} p$-value $<0.05, \quad{ }^{*} p$-value $<0.1$ 